\title{
Effect of interface condition on the undrained capacity of subsea mudmats under six degree-of-freedom loading
}

\author{
Z. Shen ${ }^{\mathrm{a}}, \mathrm{X}$. Feng ${ }^{\mathrm{b}, *}$ and S. Gourvenec ${ }^{\mathrm{b}}$
}

Published in Géotechnique 67(4):338-349 http://dx.doi.org/10.1680/jgeot.16.P.097

\section{Zhichao SHEN}

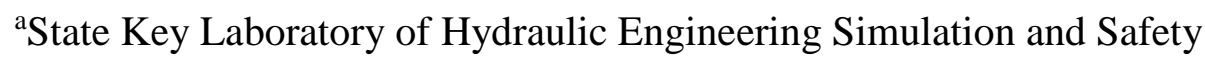

Tianjin University

92 Weijin Road, Nankai District

Tianjin, 300072

China

Visiting scholar at Centre for Offshore Foundation Systems, University of Western Australia Mobile phone: +86 15822433727

Email: shenzhch@163.com

\section{Xiaowei FENG (corresponding author)}

${ }^{\mathrm{b} C e n t r e}$ for Offshore Foundation Systems, a node of the ARC Centre of Excellence for Geotechnical Science and Engineering

University of Western Australia

35 Stirling Highway, Crawley

Perth, WA 6009

Australia

Tel: +61 864882473

Fax: +61 864881044

Email: xiaowei.feng@uwa.edu.au

\section{Susan GOURVENEC}

${ }^{\mathrm{b} C e n t r e}$ for Offshore Foundation Systems, a node of the ARC Centre of Excellence for Geotechnical Science and Engineering

University of Western Australia

Tel: +61 864883995

Email: susan.gourvenec@uwa.edu.au

No. of words: 5325 (without abstract and references)

No. of tables: 3

No. of figures: 19 


\title{
Effect of interface condition on the undrained capacity of subsea mudmats under six degree-of-freedom loading
}

\author{
Z. Shen ${ }^{\mathrm{a}}, \mathrm{X}$. Feng ${ }^{\mathrm{b}, *}$ and S. Gourvenec ${ }^{\mathrm{b}}$
}

\begin{abstract}
Effect of soil-foundation interface condition on the undrained capacity of rectangular mudmat foundations under loading in six degrees-of-freedom is investigated. Undrained failure envelopes for mudmats with zero-tension interface have been derived from finite element analyses, and compared with the solutions from traditional methods and established for an unlimited-tension interface condition. The zero-tension interface has minimal effect on failure envelopes in the absence of moment, but significantly reduces the load-carrying capacity of mudmats under all other load paths that include moment. The traditional method for predicting capacity of shallow foundations under multi-directional loading generally predicts lower capacity under any combined loading condition in comparison with the finite element results for mudmats with zero-tension interface. Algebraic expressions are proposed to describe failure envelopes for mudmats with zero-tension interface. The proposed expressions can be implemented in an automated calculation tool to enable essentially instantaneous generation of failure envelopes and optimization of a foundation design as a function of foundation dimension or material factor.
\end{abstract}

Keywords: interface; bearing capacity; footings/foundations; numerical modelling; offshore engineering 


\section{Introduction}

Subsea shallow foundations, often referred to as mudmats, are extensively employed to support subsea production infrastructure, such as pipeline end terminations and pipeline end manifolds, for oil and gas developments. To assist mudmat installation or decommissioning, perforations are commonly prefabricated on subsea mudmats. The benefits of the perforations involve (i) lowering the influence of hydrodynamic forces during deployment as water can flow through the perforations, (ii) accelerating the consolidation and thus the strength gain of the subsoil by shortening the drainage path, (iii) reducing the uplift capacity for the retrieval mudmats by limiting the development of negative excess pore pressure, i.e. suction, at mudmat invert by providing access to free water (White et al., 2005; Tapper et al., 2015; Wallerand et al., 2015). Challenges for design with perforated mudmats include (i) detrimental effect of reducing the foundation bearing capacity (White et al., 2005; Tapper et al., 2015), and (ii) loss of overturing resistance induced by the loss of base 'suction'. Results from field pullout tests indicate that even a small perforation ratio (3.1\% of the total bearing area) can reduce the peak uplift resistance by approximately 50\% (Lieng \& Bjorgen 1995) and significant reduction of $~ 70 \%$ of the peak base suction was observed in centrifuge testing on a mudmat with perforation ratio of 19\% (Li et al., 2013). In the field, the vertical load V applied to a subsea mudmat is typically small in comparison with bearing capacity whereas the lateral load $\mathrm{H}$ and the induced moment M due to tie-in and operational forces are generally the governing loads for design. Perforations in mudmats provide access to the free water and therefore limit the generation of negative excess pore pressure, i.e. base suction. Absence of base suction reduces the moment capacity of the mudmats as tensile stress cannot be transmitted by the soil-foundation interface, leading to separation of mudmats from the subsoil.

The traditional method recommended by the offshore geotechnical design guidelines (e.g. API, 2011; ISO, 2003) for shallow foundations accounts for the possible detachment from the subsoil 
under overturing moment by adopting the 'effective area' method based on the 'effective width' hypothesis (Meyerhof 1953). The approach is reasonable for predicting load-carrying capacity for strip, circular and rectangular foundations with 'zero-tension' interface (ZTI), and under eccentric vertical load (Taiebat \& Carter, 2002; Gourvenec, 2007). However, the traditional method can be conservative for the case of combined V-M-H loading due to the linear superposition of separate factors for load inclination and eccentricity (Gourvenec, 2007). The failure envelope approach has recently been proposed as an alternative to the traditional bearing capacity theory in industry guidelines (API 2011, ISO 2016) to predict the ultimate limit states of foundations under combined loading. A key advantage of the failure envelope approach is the explicit consideration of interaction of horizontal load and moment rather than the simple linear superposition of load inclination and eccentricity. Most documented failure envelopes for shallow foundations, including strip geometry (e.g. Bransby \& Randolph, 1998; Bransby \& Yun, 2009), circular (Taiebat \& Carter, 2000; Gourvenec \& Randolph, 2003) and rectangular foundations (Feng et al., 2014), were derived taking advantage of an unlimited tension interface (UTI) due to temporary negative excess pore pressure (underbase suction) relevant to unvented foundations, e.g. subsea mudmats with shallow skirts and 'sealed' top cap. In these cases, the foundation base was fully bonded to the soil without separation permitted, that is, unlimited tension can be transmitted by the soil-foundation interface. This assumption is inappropriate for perforated subsea mudmats because of the higher rate of dissipation of negative excess pore pressure. Sparse literature examines the effect of base suction on the load-carrying capacity of shallow foundations. Failure envelopes for surface foundations with ZTI under combined VM-H loading have been investigated using plastic limit analysis (Salençon \& Pecker, 1995; Ukritchon et al., 1998; Houlsby \& Puzrin, 1999) and finite element analysis (FEA) (Gourvenec 2007; Taiebat \& Carter 2010) for soil with homogenous undrained shear strength profile. The load-carrying capacity was found to be significantly reduced for foundations with ZTI 
compared with UTI, in particular at low levels of relative vertical load. V-M-H failure envelopes proposed from ZTI FEA (Gourvenec 2007) and by the traditional effective area method for rectangular foundations with ZTI (ISO 2003) are compared with FEA results with an unlimited-tension interface (UTI) condition (Feng et al., 2014) in Figure 1.

In the field, subsea mudmats are generally subjected to six degree-of-freedom loading (Figure 2) resulting from the biaxial pipeline and jumper connections. The documented failure envelopes for foundations under combined loading mostly consider co-planar V-M-H loading, without addressing the effect of the torsion $\mathrm{T}$. The response of rectangular mudmats with UTI under fully three-dimensional loading has been systematically examined (Feng et al. 2014), collapsing $\mathrm{V}-\mathrm{H}^{2}-\mathrm{M}^{2}-\mathrm{T}$ loading into a single V-M-H plane, with allowance for torsion effects. The aim of the present work is to explore the effect of interface condition on the load-carrying capacity of subsea mudmats. The framework in this paper is established based on that presented for UTI conditions by Feng et al. (2014). Results of finite element analyses carried out to investigate the undrained geotechnical response to rectangular perforated mudmats with ZTI under six degree-of-freedom loading on deposits with various degrees of shear strength heterogeneity are presented. The discrepancy between failure envelopes induced by the interface condition is presented. Algebraic expressions are proposed to describe the failure envelopes of mudmats with ZTI on soil with varying degrees of strength heterogeneity.

Undrained capacity is considered, given that the operational loading rates for subsea mudmats are determined by the rate of the heating and cooling processes of the attached pipelines, which typically take place over a few hours (Jayson et al. 2008), a time frame to ensure an undrained response around the foundation of a subsea structure in most fine grained materials (Feng \& Gourvenec 2015). 


\section{Finite element model}

\section{Geometry and mesh}

All the finite element analyses were carried out using the software ABAQUS (Dassault Systèmes, 2011). A surface rectangular mudmat with a typical breadth-to-length ratio of $B / L=$ 0.5 was considered. A half-view of the fully three-dimensional FE mesh is presented in Figure 3, showing the mesh discretisation on the central plane through the midpoint of the mudmat. The FE model comprises 50100 eight-node, hybrid brick elements (refer to C3D8H in ABAQUS element library). The location of the mesh boundaries was examined and selected to extend a distance of 3B from the edges of the mudmat and 3B beneath the mudmat, sufficiently remote that the failure mechanisms were unaffected. The mesh tie constraint available in ABAQUS was adopted to connect a fine mesh in the region close to the foundation to a coarser mesh in the far field. Mesh tie constraint allows for an abrupt transition in mesh density enabling a more time-efficient model to be established by avoiding identical mesh density throughout the whole soil domain. Mesh nodes at vertical boundaries were constrained to prevent out-ofplane displacement, while those at the base of the mesh were fully constrained in all three coordinate directions. A relatively fine mesh was generated in the vicinity of the edges of the mudmat and immediately below the mudmat to precisely capture the failure loads and mechanisms.

\section{Material properties and interface conditions}

The undrained soil shear strength $\mathrm{s}_{\mathrm{u}}$ was assumed to be uniform or increase linearly with depth according to $\mathrm{s}_{\mathrm{u}}=\mathrm{s}_{\mathrm{u} 0}+\mathrm{kz}$, as shown in Figure 2a, where $\mathrm{s}_{\mathrm{u} 0}$ is the shear strength at mudmat base level and $\mathrm{k}$ is the gradient of soil shear strength increase with depth. The degree of soil strength heterogeneity is defined by the dimensionless group $\kappa=\mathrm{kB} / \mathrm{s}_{\mathrm{u} 0}$, ranging from 0 (uniform soil) to 10. The undrained soil condition was represented with a linear elastic perfectly plastic constitutive law obeying the Tresca failure criterion. A constant modulus ratio of $E_{u} / s_{u}=1000$ 
was prescribed, enabling failure loads to be mobilised with relatively small deformation to minimise mesh distortion. The undrained limit state of the soil is the focus of the work, which is independent of the magnitude of $\mathrm{E}_{\mathrm{u}}$. To avoid numerical difficulties the Poisson's ratio of $v$ $=0.49$ was adopted to approximate the constant volume response of soil under undrained conditions. The mudmat was modelled as a weightless, rigid body, with the load reference point (LRP) located at the midpoint of the mudmat base.

The contact between the mudmat and subsoil was modelled by a zero tension interface, ZTI. The behaviour of a ZTI can be understood as a limiting case of a non-dilative frictional interface with an angle of friction approaching $90^{\circ}$ (Houlsby \& Puzrin, 1999). The Coulomb friction model with a coefficient of friction $\mu=20$ (i.e. the equivalent friction angle of $\varphi=\tan ^{-1} 20$, $87.1^{\circ}$ ) was adopted to simulate the ZTI (Shen et al. 2016). The interface therefore has a shear limit identical with the undrained shear strength of the soil in contact with the foundation such that shear failure in the interface means shear failure of the soil adjacent to the foundation base. This assumption might be challenged by the shear behaviour of some structural and sensitive natural deep-ocean clay crust, as reported in Kuo \& Bolton (2014). The surface-to-surface contact incorporated with the small-sliding tracking approach was employed to model the soilfoundation interface.

\section{Sign conventions and nomenclature}

Downward vertical load, with left-to-right horizontal load and clockwise moment are taken as positive. The sign convention is shown in Figure 2. The ultimate vertical, horizontal and torsional capacities are defined as the corresponding maximum loads mobilised in the absence of any other loading. However, the ultimate moment capacity is considered as the maximum available overturning resistance mobilised in conjunction with a vertical load, since that moment capacity diminishes with reducing vertical load and no moment capacity is available in the absence of vertical load for mudmats with ZTI. 


\section{Loading path}

Combined load-carrying capacity of mudmats is presented in the form of failure envelopes. Sideswipe tests are employed to identify failure loads in the V-H and V-T loading planes, for which they have been shown to work well. For load combinations including V-M-H, V-H-T and V-M-T, a vertical load V was initially imposed to mudmats as a proportion of the ultimate vertical capacity and maintained constant throughout the analysis. Immediately after the application of the vertical load, the fixed ratio displacement-controlled probe tests (Gourvenec \& Randolph, 2003) were conducted to detect the failure envelopes. Only a single point can be provided on the failure envelope by a fixed displacement ratio probe test and failure is defined where the normal to the load path matches the prescribed displacement ratio. An example of the $\mathrm{V}-\mathrm{H}_{\mathrm{x}}-\mathrm{M}_{\mathrm{y}}$ failure envelope for $\kappa=0$ and the corresponding probes is presented in Figure 4a. The load-displacement curves for the load paths of $\mathrm{u} / \mathrm{B} \omega=0.6$ and $\mathrm{u} / \mathrm{B} \omega=-0.6$ are shown respectively in Figure $4 \mathrm{~b}$ and c, indicating that the failure loads are achieved with either the horizontal load or the moment reaching its limit. For the general $\mathrm{V}-\mathrm{H}^{2}-\mathrm{M}^{2}-\mathrm{T}$ loading, an intermediate step applying a constant torsion $\mathrm{T}$ was included between the application of the vertical load and the execution of the probe tests.

\section{Results}

\section{Pure uniaxial capacity and validation}

No separation of a mudmat from the soil will occur under a vertical (compressive) load. The ultimate vertical capacity $\mathrm{V}_{\text {ult }}$ for a surface rectangular mudmat of $\mathrm{B} / \mathrm{L}=0.5$ with ZTI can be predicted by equation (1) considering the effect of soil heterogeneity, as proposed by Feng et al. (2014) for UTI.

$$
\frac{V_{u l t}}{A s_{u 0}}=5.7 \times\left(1+0.2 \kappa-0.012 \kappa^{2}+0.0004 \kappa^{3}\right)
$$


where A is the mudmat bearing area. More recently, upper bound and lower bound solutions for the vertical bearing capacities for rectangular mudmats with UTI have been reported by Martin et al. (2015). Current FE results fall within 2\% of the upper bound (UB) and 8\% of the lower bound (LB) for all degrees of soil strength heterogeneity. The vertical bearing capacity factors derived by FE analysis compared with that by plasticity limit analysis are shown in Figure 5. Equation (1) is not valid when $B / L$ deviates from the common value of 0.5 , thus a full suite of analyses would be required for other aspect ratios.

The horizontal capacity for a surface mudmat is theoretically the product of the mudmat base area $\mathrm{A}$ and soil shear strength at mudmat base level $\mathrm{s}_{\mathrm{u} 0}$. The over-prediction by FE increases slightly with the increasing degree of soil strength heterogeneity due to the non-zero thickness of interface elements, up to $5 \%$ in $\mathrm{H}_{\text {xult }}$ and $4 \%$ in $\mathrm{H}_{\text {yult }}$ for the case of $\kappa=10$.

The torsional capacity, $\mathrm{T}_{\mathrm{ult}} / \mathrm{ALs}_{\mathrm{u} 0}$, obtained numerically ranged from 0.31 for $\kappa=0$ (homogenous soil) to 0.32 for $\kappa=10$, compared with the analytical solution, independent of soil strength heterogeneity, of 0.30 (rounded for 0.297, see equation (14) in Murff et al. 2010). The dimensionless ultimate moment capacity $\mathrm{M}_{\mathrm{yult}} / \mathrm{ABs}_{\mathrm{u} 0}$ and $\mathrm{M}_{\mathrm{xult}} / \mathrm{ALs}_{\mathrm{u} 0}$ obtained from this study are summarised in Table 1 along with predictions from the traditional effective area method (EAM) (ISO 2003) for varying degrees of soil strength heterogeneity. Ultimate moment was mobilised in conjunction with a vertical load of approximately $50 \%$ of the ultimate vertical capacity for each level of strength heterogeneity. The analysed $\mathrm{M}_{\mathrm{yult}} / \mathrm{ABs}_{\mathrm{u} 0}$ by the FE method is $6 \%$ higher than predicted by the traditional method for homogeneous soil and the disparity diminishes as the soil strength heterogeneity increases. The FE results of $\mathrm{M}_{\mathrm{xult}} / \mathrm{ALs}_{\mathrm{u} 0}$ generally agree with the traditional method, with an exceptional under-prediction for uniform soil. The FE results of the ultimate moment capacity considering the degree of soil strength heterogeneity can be fitted by quadratic polynomials. 


$$
\begin{aligned}
& \frac{M_{\mathrm{yult}}}{A B s_{\mathrm{u} 0}}=0.71+0.09 \kappa-0.0038 \kappa^{2} \\
& \frac{M_{\mathrm{xult}}}{A L s_{\mathrm{u} 0}}=0.74+0.1 \kappa-0.0029 \kappa^{2}
\end{aligned}
$$

\section{Failure envelopes for biaxial loading planes including V}

\section{Vertical-Horizontal loading}

Figure 6 compares the dimensionless $\mathrm{V}-\mathrm{H}$ failure envelopes derived from FEA with that determined by the traditional method for mudmats with different interface conditions. In the V$\mathrm{H}_{\mathrm{x}}$ loading plane, FE results agree well with the traditional solution for soil with uniform strength with depth, i.e., the conditions for which it was derived. The envelopes diverge increasingly with increasing degree of soil strength heterogeneity showing that simple scaling of the envelope by the ultimate vertical and horizontal limit states does not capture accurately the effect of strength heterogeneity on V-H capacity. The discrepancy of the traditional solution from the FE results is greater in the $\mathrm{V}-\mathrm{H}_{\mathrm{y}}$ loading plane.

The failure envelopes for the mudmat with ZTI are identical to those with UTI, implying that the effect of interface condition is minimal on the combined V-H capacity because the effective soil-foundation contact area for ZTI is essentially intact due to the absence of overturning moment. Therefore, the normalised V-H failure envelopes for mudmats with ZTI can be described using equation (3) proposed by Feng et al. (2014) for mudmats with UTI, irrespective of the degrees of soil strength heterogeneity, $\kappa$ (Figure 7). The vertical load $\mathrm{V}$ and horizontal load $\mathrm{H}$ are normalised by the corresponding ultimate values as $\mathrm{v}=\mathrm{V} / \mathrm{V}_{\mathrm{ult}}, \mathrm{h}=\mathrm{H}_{\mathrm{x}} / \mathrm{H}_{\mathrm{xult}}$ (for $\theta=$ $\left.0^{\circ}\right)$ or $\mathrm{h}=\mathrm{H}_{\mathrm{y}} / \mathrm{H}_{\text {yult }}\left(\right.$ for $\left.\theta=90^{\circ}\right)$.

$$
\begin{array}{ll}
h=\left[1-\left(\frac{v-0.5}{0.5}\right)^{2}\right]^{\frac{1}{2.5-\cos ^{2} \theta}} & \text { for } \mathrm{v}>0.5 \\
h=1 & \text { for } \mathrm{v} \leq 0.5
\end{array}
$$


where $\theta$ is the angle of horizontal loading from the short side of the mudmat foundation (Figure 2b).

\section{Vertical-Moment loading}

Figure 8 presents the V-M failure envelopes for mudmats from FEA with ZTI and UTI and those derived from the EAM. The moment capacity for mudmats with ZTI is a parabolic function of the vertical load mobilisation, with the maximum value mobilised at approximately $\mathrm{v}=\mathrm{V} / \mathrm{V}_{\mathrm{ult}}=0.5$. In contrast, the moment capacity for mudmats with UTI shows a consistent decrease as the vertical load increases. The load-carrying capacity of the mudmats with ZTI agrees well with that of UTI for $\mathrm{v} \geq 0.7$ and 0.75 in the $\mathrm{V}-\mathrm{M}_{\mathrm{y}}$ and $\mathrm{V}-\mathrm{M}_{\mathrm{x}}$ plane, respectively, where the detachment of mudmats from the soil is minimal. The failure envelopes obtained from FEA for mudmats with ZTI are marginally higher than predicted by the EAM due to the slight over-prediction of uniaxial vertical and moment capacities in the FEA as described above. Figure 9 shows that the normalised V-M failure envelopes for ZTI predicted from the FEA agree well with the EAM, and also that they are insensitive to the degree of soil strength heterogeneity, in contrast to those for mudmats with UTI, which contract significantly with increasing soil strength heterogeneity.

The normalised V-M failure envelopes for a mudmat with ZTI can be described by a parabola defined by equation (4), as proposed by Gourvenec (2007) for rectangular foundations on homogeneous deposits.

$$
m=4 v(1-v)
$$

The failure envelope predicted by equation (4) is shown in Figure 9 against that derived from FEA and the EAM. The expression accurately describes the shape of the normalised failure envelopes in the $\mathrm{V}-\mathrm{M}_{\mathrm{y}}$ and $\mathrm{V}-\mathrm{M}_{\mathrm{x}}$ loading planes, implying that the shape of the normalised $\mathrm{V}$ $\mathrm{M}$ failure envelopes is independent of moment angle $\theta_{\mathrm{m}}$ for mudmats with ZTI. This is in contrast to the findings for mudmats with UTI (Feng et al., 2014).The validity of equation (4) 
for predicting the normalised V-M failure envelopes for strip and circular foundations was recently shown by Shen et al. (2016). Therefore, equation (4) is considered to be appropriate for any foundation geometry and any linearly increasing soil strength profile.

\section{Vertical-Torsion loading}

The failure mechanism for a surface mudmat under combined V-T loading is similar to that for combined V-H loading. The V-T failure envelopes for mudmats with ZTI and UTI are also similar due to the absence of overturning moment. Feng et al. (2014) proposed a general expression to describe the normalised V-T failure envelopes for UTI conditions that can be applied to ZTI conditions.

$$
\begin{array}{ll}
t=\left[1-\left(\frac{v-0.5}{0.5}\right)^{2}\right]^{0.4} & \text { for } \mathrm{v}>0.5 \\
t=1 & \text { for } \mathrm{v} \leq 0.5
\end{array}
$$

Equation (5) is presented together with FE results in Figure 10, showing divergence of less than $5 \%$.

\section{Resultant horizontal and moment capacities}

\section{Biaxial horizontal loading}

The resultant horizontal capacity $\mathrm{H}_{\text {ult }}$ in any direction can be resolved on the failure envelopes for biaxial horizontal loading, which were determined by fixed displacement ratio probe tests. For a surface mudmat, soil shearing failure governs the sliding mechanism and the pure horizontal capacity equals the product of the mudmat bearing area, A, and soil shear strength at mudmat base level, su0, irrespective of the soil strength heterogeneity, $\kappa$, and loading direction, $\theta$. Therefore, the shape of the normalised $\mathrm{H}_{\mathrm{x}}-\mathrm{H}_{\mathrm{y}}$ failure envelope is theoretically circular, expressed as 


$$
\left(\frac{H_{x}}{H_{\text {xult }}}\right)^{2}+\left(\frac{H_{y}}{H_{\text {yult }}}\right)^{2}=1 \quad \text { for } 0 \leq \kappa \leq 10 ; \mathrm{v} \leq 0.5 ; \mathrm{M}=\mathrm{T}=0
$$

Figure 11 shows failure envelopes derived by equation (6) compared with those from FE analysis.

\section{Biaxial moment}

Overturning moment cannot be sustained by mudmats with ZTI in the absence of vertical load and the ultimate moment capacity is mobilised at a vertical load mobilisation of approximately $\mathrm{v}=0.5$. Therefore, the failure envelopes for biaxial moment capacity for $\mathrm{v}=0.5$ for mudmats with ZTI are compared with those for v $=0$ for mudmats with UTI in Figure 12a. Both the FE results and the EAM indicate that the soil strength profile has minimal effect on the shape of failure envelopes for the case of ZTI, whereas the failure envelopes for the case of UTI contract with the increasing soil strength heterogeneity and gradually converge to the failure envelope for the case of ZTI for high values of $\kappa(>10)$ (Figure 12b). The convergence of the normalised failure envelopes could arise since soil failure mechanisms becomes shallower with increasing soil strength heterogeneity for UTI, while are always shallow with ZTI due to the detachment of the foundation under the action of the moment.

The shape of the normalised $\mathrm{M}_{\mathrm{y}}-\mathrm{M}_{\mathrm{x}}$ failure envelopes can be described by equation (7), expressed as

$$
\left(\frac{M_{y}}{M_{\text {yult }}}\right)^{1.5}+\left(\frac{M_{x}}{M_{\text {xult }}}\right)^{2}=1 \quad \text { for } 0 \leq \kappa \leq 10 ; \mathrm{v}=0.5 ; \mathrm{H}=\mathrm{T}=0
$$

The quality of this fit is shown in Figure 12b.

For a given moment direction $\theta_{\mathrm{m}},=\tan ^{-1}\left(\mathrm{M}_{\mathrm{y}} / \mathrm{M}_{\mathrm{x}}\right)$, the failure moment $\mathrm{M}_{\mathrm{y}}$ and $\mathrm{M}_{\mathrm{x}}$ can be derived with equation (7), yielding the ultimate moment capacity, $\mathrm{M}_{\mathrm{ult}}=\left(\mathrm{M}_{\mathrm{y}}^{2}+\mathrm{M}_{\mathrm{x}}^{2}\right)^{1 / 2}$. 


\section{Combined resultant $\mathrm{H}-\mathrm{M}$ failure envelopes}

Figure 13 shows the $\mathrm{H}-\mathrm{M}$ failure envelopes at vertical load mobilisation of $\mathrm{v}=0.5$ for rectangular mudmats with ZTI and UTI. For the case of UTI and for a given vertical load, the maximum moment is mobilised when $\mathrm{H}$ and $\mathrm{M}$ act in the same direction (i.e. left-to-right and clockwise or vice-versa). For the case of ZTI, the maximum moment is mobilised at zero horizontal load.

Figure 14 enables comparison of the shape of the failure envelopes for the mudmats with ZTI through plotting in normalised load space, V-M-H. The failure envelopes for the ZTI become more asymmetrical with increasing vertical load mobilisation and degree of shear strength heterogeneity, and limited effect of soil strength heterogeneity is observed when the $\mathrm{H}$ and $\mathrm{M}$ act in the same direction - opposite to the trend for UTI. Failure envelopes derived from the EAM are always symmetric because of the assumption that the response of the foundation is independent of the direction of the coupled H-M loading. The EAM under-predicts the capacity for mudmats with ZTI compared with the FE results due to the linear superposition of modification factors for the load inclination and eccentricity.

Normalised V-M-H failure envelopes for rectangular mudmats with ZTI can be described by an elliptical expression, as

$$
\left(\frac{H}{H_{\text {max_1 }}}\right)^{2}+\left(\frac{M}{M_{\text {max_1 }_{1}}}\right)^{q}=1 \quad \text { for } 0 \leq \kappa \leq 10 ; \mathrm{v} \leq 0.5 ; \mathrm{T}=0
$$

where $\mathrm{H}_{\max \_1}$ and $\mathrm{M}_{\max \_1}$ are the maximum horizontal load and moment considering the vertical load mobilisation. The exponent of $\mathrm{q}=(2-\mathrm{v})$ is recommended, compared with $\mathrm{q}=2$ suggested by Gourvenec (2007) for rectangular mudmats with ZTI on deposits with uniform strength with depth $(\kappa=0)$, without considering the effect of vertical load mobilisation.

While equation (8) does not capture the asymmetry induced by the soil strength heterogeneity $\kappa$, when $\mathrm{H}$ and $\mathrm{M}$ act in opposition, since in many field conditions, moment derives from an 
eccentrically applied horizontal load so that these two components typically act in the same direction, and as such the simple symmetrical elliptical expression is considered appropriate and pragmatic as a single unifying expression.

Equation (8) is shown to provide a close approximation to the normalised $H_{x}-M_{y}$ and $H_{y}-M_{x}$ failure envelopes for rectangular mudmats with ZTI for varying soil strength heterogeneity $\kappa$ in Figure 13 (with errors within 3\%), indicating that the shape of $\mathrm{H}-\mathrm{M}$ failure envelopes for mudmats with ZTI is insensitive of the direction of horizontal load, in contrast with the case of UTI as discussed in Feng et al. (2014). The maximum resultant horizontal load $\mathrm{H}_{\text {max_1 }}$ can be derived by equation (6). For the case considered in this study, i.e. a surface mudmat under vertical load mobilisation $v \leq 0.5$, the maximum resultant horizontal load $\mathrm{H}_{\text {max } \_1}=\mathrm{H}_{\mathrm{ult}}=\mathrm{Asu0}$, irrespective of horizontal load angle $\theta$ and soil strength heterogeneity factor $\kappa$. The maximum resultant moment $\mathbf{M}_{\max _{-} 1}$ for any moment angle $\theta_{\mathrm{m}}$ and any vertical load mobilisation can be calculated through equation (4) and equation (7).

\section{Effect of torsion on resultant horizontal and moment capacity}

An interaction diagram between horizontal load and torsion was proposed by Finnie and Morgan (2004), as

$$
\left(\frac{H}{H_{\text {max_1 }}}\right)^{l}+\left(\frac{T}{T_{\text {max_1 }}}\right)^{n}=1 \quad \text { for } 0 \leq \kappa \leq 10 ; \mathrm{v} \leq 0.5 ; \mathrm{M}=0
$$

where the powers $\mathrm{l}$ and $\mathrm{n}$ are a function of the direction of horizontal load, $\theta$, as proposed by Feng et al. (2014) by

$$
\begin{aligned}
& l=0.85 \\
& n=1.25+0.75(\sin \theta)^{2.5}
\end{aligned}
$$

Equation (10) was derived for normalised H-T failure envelopes for the case of UTI, and for any given value of $\theta$. Since the detachment of the foundation is minimal in the absence of moment, equations (9) and (10) can still accurately describe failure envelopes for the case of 
ZTI for $v \leq 0.5$. Figure 15 presents the FE results of the two extreme cases of $\theta=0^{\circ}$ and $\theta=90^{\circ}$ to show the quality of the curve fitting. The maximum resultant horizontal load $H_{\text {max }_{-}}$is the same as that defined in equation (8). Equation (5) indicates that the maximum torsion, $\mathrm{T}_{\text {max } \_1}=$ $\mathrm{T}_{\text {ult }}$ for $\mathrm{v} \leq 0.5$.

Figure 16 compares the ultimate load-carrying capacity under T-M loading for ZTI with the vertical load mobilisation of $\mathrm{v}=0.5$ with that for UTI at $\mathrm{v}=0$. The available maximum torsional capacity is largely reduced for ZTI due to the detachment of the mudmat from the soil under the action of moment. In contrast with $\mathrm{H}-\mathrm{T}$ interaction, the load-carrying capacity under T-M loading depends significantly on the vertical load mobilisation. However, the effect of the vertical load mobilisation is minimal on the shape of T-M failure envelopes, expressed as

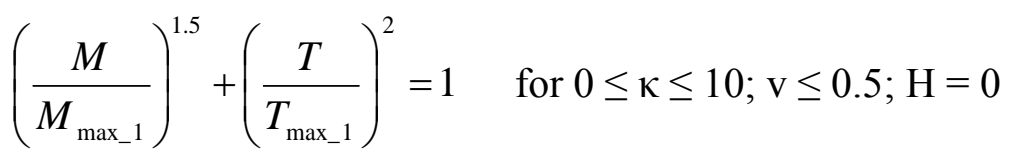

where $M_{\max _{\_} 1}$ and $T_{\max _{1} 1}$ follow the definitions given in equation (8) and equation (9) respectively. The quality of fit for FE results by equation (11) is illustrated in Figure 17 (a) and (b).

\section{Effect of torsion on combined resultant $H-M$ failure envelopes}

The normalised H-M failure envelopes at intervals of torsion mobilisation are shown in Figure 18, illustrating that the size of the normalised failure envelopes contracts proportionally with increasing torsion. Therefore, the strategy employed by Feng et al. (2014) for the case of UTI is applicable for ZTI to consider the effect of torsion. Equation (8) can be adjusted by reducing the horizontal load and moment used for normalisation, $H_{\max \_1}$ and $M_{\max \_1}$, to $H_{\max _{\_} 2}$ and $M_{\max \_2}$, with allowance for torsion mobilisation, to give

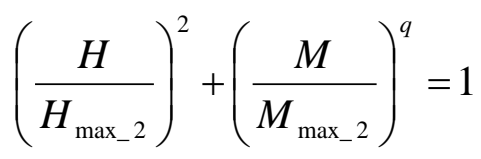


where $\mathrm{H}_{\max \_2}$ and $\mathrm{M}_{\max \_2}$ are the maximum available horizontal load and moment for given torsion $\mathrm{T}$ and can be derived from the H-T interaction diagram by equation (9) and M-T interaction diagram by equation (11), respectively. The same power of $q=(2-v)$ as adopted in equation (8) was adopted to describe the shape of failure envelopes.

Failure envelopes derived by equation (12) are compared with predictions from the FE analysis in Figure 18. Equation (12) gives good prediction for the normalised H-M failure envelopes for low soil strength heterogeneity. As the soil strength heterogeneity increases, the goodness of the fit decreases but the equation still gives a reasonable estimation for the failure envelopes in the positive H-M quadrant, which is the commonplace since overturing moment is generally induced by eccentrically applied horizontal load.

\section{Example application}

Two examples are considered to demonstrate the effect of interface condition on the design of mudmats. The input data for the two examples are summarised in Table 2, including the foundation geometry, soil strength profile and (factored) design loads. The only differences between the examples are the design horizontal load $\mathrm{H}_{\mathrm{x}}=80 \mathrm{kN}$ or $20 \mathrm{kN}$ and the induced moment $\mathrm{M}_{\mathrm{y}}=480 \mathrm{kNm}$ or $120 \mathrm{kNm}$ in Examples 1 and 2 respectively. A constant ratio of $\mathrm{M}_{\mathrm{y}} / \mathrm{H}_{\mathrm{x}}$ $=6$ is maintained, that is, the load acts at a constant eccentricity above the mudmat. The loading paths in the resultant $\mathrm{H}-\mathrm{M}$ loading plane are therefore different for the two examples. The material factor, $\gamma_{\mathrm{m}}$, defined as the partial safety factor for the soil shear strength is estimated for cases of ZTI and UTI. The approach presented in Feng et al. (2014) is established for subsea mudmats with UTI, whereas the following steps are executed for the mudmat with ZTI.

Step 1: Evaluate the dimensionless quantities $\mathrm{B} / \mathrm{L}$ and $\kappa=\mathrm{kB} / \mathrm{s}_{\mathrm{u} 0}$.

Step 2: Calculate the uniaxial capacities and evaluate the load mobilisation. The vertical and moment capacities, $V_{\text {ult }}, M_{\text {yult }}$ and $M_{\text {xult }}$ are estimated by equations (1) and (2). For the surface 
mudmat considered, the uniaxial horizontal capacity $\mathrm{H}_{\mathrm{xult}}=\mathrm{H}_{\mathrm{yult}}=\mathrm{As} \mathrm{u}$, and the torsional capacity, $\mathrm{T}_{\mathrm{ult}}=0.297 \mathrm{ALs}_{\mathrm{u} 0}$.

Step 3: Evaluate the available resultant horizontal, overturing and torsional resistance considering the vertical load mobilisation $\mathrm{v}=\mathrm{V} / \mathrm{V}_{\mathrm{ult}}$. The horizontal resistance $\mathrm{H}_{\text {max }_{\_} 1}$ for given direction of loading $\theta=\tan ^{-1}\left(\mathrm{H}_{\mathrm{y}} / \mathrm{H}_{\mathrm{x}}\right)$ is determined on the $\mathrm{H}_{\mathrm{x}}-\mathrm{H}_{\mathrm{y}}$ plot described by equation (6). The loading direction was maintained constant, which may be invalid in certain cases if loading direction changed with resistance mobilisation. The ultimate moment capacity $\mathrm{Mult}_{\mathrm{ut}}$ for given $\theta_{\mathrm{m}}=\tan ^{-1}\left(\mathrm{M}_{\mathrm{y}} / \mathbf{M}_{\mathrm{x}}\right)$ can be derived from equation (7) and the maximum available moment $\mathbf{M}_{\text {max } \_1}$ accounting for the vertical load mobilisation through equation (4). The torsional resistance $\mathrm{T}_{\text {max_1 }}$ can be obtained from equation (5).

Step 4: Reduce the horizontal capacity $\mathrm{H}_{\max _{-} 1}$ and the moment capacity $\mathrm{M}_{\max _{-} 1}$ to $\mathrm{H}_{\max _{-} 2}$ and

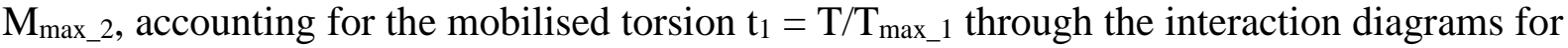
H-T and T-M loading by equations (9) and (11), respectively.

Step 5: Plot the resultant H-M failure envelope using equation (12).

Step 6: Assess the material factor of the soil undrained shear strength.

The results of Example 1 are collected in Table 3. The factored failure envelopes accounting for the material factor $\gamma_{\mathrm{m}}$ are illustrated in Figure 19 for the two example applications to assess the effects of interface condition. In Example 1, the overturning moment is more dominant and the detachment of the mudmat from the soil is therefore more significant. The calculated material factor is 1.50 if a UTI is assumed in the prediction, i.e. without considering the separation of the mudmat from the soil, while a material factor of 0.97 is predicted if a ZTI assumed, using the method proposed in this paper. It is clear that the interface condition should be evaluated carefully for this case. Mudmat sliding governs failure in Example 2 and the detachment of the foundation from the soil is minimal. The difference in material factor for the two cases is therefore less significant; 1.60 for a mudmat with ZTI compared with 1.80 for the 
UTI condition. The two examples included here were selected to demonstrate that the interface condition needs to be considered for a particular loading path. Inappropriate assessment of tension capacity transmitted by the interface can lead to unsafe design.

\section{Conclusions}

Undrained failure envelopes for mudmats with zero tension interface (ZTI) derived from finiteelement analysis have been compared with those determined from the traditional effective area method (EAM) and those previously established for an unlimited tension interface (UTI).The interface condition has negligible influence on the capacity of mudmats under combined $\mathrm{V}-\mathrm{H}$, V-T and V-H-T loading due to the absence of overturning moment, that is, a shallow mechanism under H-T loading dominates the failure. The load-carrying capacity of the mudmats with zero-tension interface is reduced significantly under the action of the overturning moment because of the detachment of the mudmat from the subsoil.

The V-M failure envelopes for the zero-tension interface condition are parabolas with the ultimate moment capacity mobilised around $\mathrm{V}=0.5 \mathrm{~V}_{\text {ult }}$, whereas the mobilised overturning resistance increases consistently as vertical load mobilisation decreases for an unlimitedtension interface, with the ultimate moment capacity achieved at $\mathrm{V}=0$. The size and shape of the failure envelopes are significantly affected by the interface condition. The failure envelopes for ZTI fall inside those for UTI for all vertical load mobilisations and any soil strength heterogeneity because of loss of effective bearing area under overturning moment. The size of the normalised H-M failure envelopes for mudmats with ZTI contracts proportionally with increasing torsion mobilisation. The method established for considering the torsion effect for mudmats with UTI is valid for mudmats with zero-tension interface by scaling the H-M failure envelopes with the reduced maximum resultant horizontal load and moment used for normalisation according to the $\mathrm{H}-\mathrm{T}$ and $\mathrm{M}-\mathrm{T}$ interaction. 
In comparison with the results of FEA for the ZTI, the EAM provides best prediction for the load-carrying capacity under combined V-M loading and is generally conservative for all other loading conditions, implying that the effective area principle reflects the response of the mudmats under eccentric vertical load. However, the simple superposition with the separate solutions for load inclination and eccentricity compromises the accuracy for predicting V-M-H capacity.

A series of expressions are proposed for predicting the undrained failure envelopes for the rectangular mudmats with zero-tension interface. The algebraic expressions can be conveniently implemented into an automated calculation tool to enable essentially instantaneously generation of failure envelopes or optimization a particular geotechnical design as a function of foundation size or material factor. Two example applications are presented to demonstrate the effect of interface condition on the capacity of mudmats. The interface condition needs to be considered carefully for particular loading paths under which the detachment of mudmat from the soil is significant.

The work presented in this paper provides new insights into the load-carrying capacity of subsea mudmats with zero-tension interface and is beneficial for the geotechnical design of perforated mudmats as transient tension (relative to ambient pressure) cannot be resisted through generation of the base suctions.

\section{Acknowledgements}

This work forms part of the activities of the Centre for Offshore Foundation Systems (COFS). Established in 1997 under the Australian Research Council’s Special Research Centres Program. Supported as a node of the Australian Research Council's Centre of Excellence for Geotechnical Science and Engineering, and through the Fugro Chair in Geotechnics, the Lloyd's Register Foundation Chair and Centre of Excellence in Offshore Foundations and the 
Shell EMI Chair in Offshore Engineering. The second author is supported by the Lloyd's Register Foundation and ARC grant DP140100684. Lloyd's Register Foundation helps to protect life and property by supporting engineering-related education, public engagement and the application of research. The third author is supported through ARC grant CE110001009. The work presented in this paper is supported through Australian Research Council Discovery Project Grant DP140100684. The first author worked on the research project presented in this paper while a visiting scholar at the Centre for Offshore Foundation Systems (COFS), UWA, supported through a China Scholarship Council (CSC) scholarship and the Australia-China Natural Gas Technology Partnership Fund Top-Up Scholarship and by State Key Laboratory of Hydraulic Engineering Simulation and Safety (Tianjin University). This support is gratefully acknowledged.

\section{Notation}

\begin{tabular}{|c|c|}
\hline A & Mudmat bearing area \\
\hline $\mathrm{B}$ & Mudmat breadth \\
\hline $\mathrm{E}_{\mathrm{u}}$ & Young's modulus \\
\hline $\mathrm{H}$ & Resultant horizontal load \\
\hline $\mathrm{H}_{\text {ult }}$ & Ultimate horizontal capacity for given $\theta$ \\
\hline $\mathrm{H}_{\max \_1}$ & Maximum horizontal resistance considering the vertical load mobilisation \\
\hline $\mathrm{H}_{\max \_2}$ & $\begin{array}{l}\text { Maximum horizontal resistance considering the vertical and torsional load } \\
\text { mobilisation }\end{array}$ \\
\hline $\mathrm{H}_{\mathrm{x}}$ & Horizontal load along $\mathrm{x}$ - direction \\
\hline $\mathrm{H}_{\mathrm{y}}$ & Horizontal load along y- direction \\
\hline $\mathrm{H}_{\mathrm{xult}}$ & Ultimate horizontal capacity along $\mathrm{x}$ - direction \\
\hline $\mathrm{H}_{\text {yult }}$ & Ultimate horizontal capacity along y- direction \\
\hline $\mathrm{L}$ & Mudmat length \\
\hline M & Resultant moment \\
\hline $\mathrm{M}_{\max \_1}$ & Maximum moment resistance considering the vertical load mobilisation \\
\hline $\mathrm{M}_{\max \_2}$ & $\begin{array}{l}\text { Maximum moment resistance considering the vertical and torsional load } \\
\text { mobilisation }\end{array}$ \\
\hline $\mathrm{M}_{\mathrm{x}}$ & Moment about $\mathrm{x}$ - direction \\
\hline $\mathrm{M}_{\mathrm{y}}$ & Moment about y- direction \\
\hline $\mathrm{M}_{\mathrm{ult}}$ & Ultimate moment capacity for given $\theta_{\mathrm{m}}$ \\
\hline $\mathrm{M}_{\text {xult }}$ & Ultimate moment capacity about $\mathrm{x}$ - direction \\
\hline$M_{\text {yult }}$ & Ultimate moment capacity about y- direction \\
\hline $\mathrm{V}$ & Vertical load \\
\hline $\mathrm{V}_{\text {ult }}$ & Vertical capacity \\
\hline
\end{tabular}




$\begin{array}{ll}\mathrm{T} & \text { Torsion } \\ \mathrm{T}_{\mathrm{ult}} & \text { Ultimate torsional capacity } \\ \mathrm{h} & \text { Normalised horizontal load, } \mathrm{h}=\mathrm{H} / \mathrm{H}_{\mathrm{ult}} \\ \mathrm{k} & \text { Gradient of undrained shear strength } \\ \mathrm{l} & \text { Power in the expression for the normalised H-T failure envelopes } \\ \mathrm{m} & \text { Normalised moment capacity, } \mathrm{m}=\mathrm{M} / \mathrm{M}_{\mathrm{ult}} \\ \mathrm{n} & \text { Power in the expression for the normalised H-T failure envelopes } \\ \mathrm{q} & \text { Exponent in the expression for the normalised H-M failure envelopes } \\ \mathrm{S}_{\mathrm{u}} & \text { Undrained shear strength } \\ \mathrm{u} & \text { Horizontal displacement } \\ \mathrm{S}_{\mathrm{u} 0} & \text { Undrained shear strength at mudmat base level } \\ \mathrm{t} & \text { Normalised torsion, } \mathrm{t}=\mathrm{T} / \mathrm{T}_{\mathrm{ult}} \\ \mathrm{v} & \text { Normalised vertical load, } \mathrm{v}=\mathrm{V} / \mathrm{V}_{\mathrm{ult}} \\ \gamma_{\mathrm{m}} & \text { Material factor } \\ \theta & \text { Horizontal loading direction, } \theta=\tan ^{-1}\left(\mathrm{H}_{\mathrm{y}} / \mathrm{H}_{\mathrm{x}}\right) \\ \theta_{\mathrm{m}} & \text { Moment direction, } \theta_{\mathrm{m}}=\text { tan }^{-1}\left(\mathrm{M}_{\mathrm{y}} / \mathrm{M}_{\mathrm{x}}\right) \\ \kappa & \text { Degree of soil strength heterogeneity } \\ \mu & \text { Coefficient of friction } \\ \varphi & \text { Friction angle } \\ \mathrm{v} & \text { Poisson's ratio } \\ \omega & \text { rotation }\end{array}$

\section{References}

API (2011) Recommended Practice 2GEO Geotechnical and Foundation Design Considerations - $1^{\text {st }}$ Edition. Washington, American Petroleum Institute.

Bransby, M. F. \& Randolph, M. F. (1998) Combined loading of skirted foundations. Géotechnique 48(5):637-655, http://dx.doi.org/10.1680/geot.1998.48.5.637.

Bransby, M. F. \& Yun, G. J. (2009) The undrained capacity of skirted strip foundations under combined loading. Géotechnique 59(2):115-125, http://dx.doi.org/10.1680/geot.2007.00098.

DassaultSystèmes. (2011) ABAQUS 6.11 Analysis User's Manual. Simulia Corp, Providence, RI, USA.

Feng, X. \& Gourvenec, S. (2015) Conslidated undrained load-carrying capacities of subsea mudmats under combined loading in six degrees of freedom. Géotechnique 65(7):563575, http://dx.doi.org/10.1680/geot.14.P.090.

Feng, X., Randolph, M. F., Gourvenec, S. \&Wallerand, R. (2014) Design approach for rectangular mudmats under fully three-dimensional loading. Géotechnique 64(1):51-63, http://dx.doi.org/10.1680/geot.13.P.051.

Gourvenec, S. (2007) Shape effects on the capacity of rectangular footings under general loading. Géotechnique 57(8):637-646, http://dx.doi.org/10.1680/geot.2007.57.8.637.

Gourvenec, S. \& Randolph, M. (2003) Effect of strength non-homogeneity on the shape of failure envelopes for combined loading of strip and circular foundations on clay. Géotechnique 53(6):575-586, http://dx.doi.org/10.1680/geot.2003.53.6.575. 
Houlsby, G. T. \&Puzrin, A. M. (1999) The bearing capacity of a strip footing on clay under combined loading. Proceedings of the Royal Society of London. Series A: Mathematical, Physical and Engineering Sciences 455(1983):893-916, http://dx.doi.org/10.1098/rspa.1999.0340.

ISO (2003) ISO19901-4: Petroleum and natural gas industries specific requirements for Offshore Structures - Part 4: Geotechnical and foundation design considerations - $1^{\text {st }}$ Eidition. Geneva, International Standards Organisation.

ISO (2016) ISO19901-4: Petroleum and natural gas industries specific requirements for Offshore Structures - Part 4: Geotechnical and foundation design considerations - $2^{\text {nd }}$ Eidition. Geneva, International Standards Organisation, In Press.

Jayson, D., Delaporte, P., Albert, J.-P., Prevost, M.-E., Bruton, D. \& Sinclair, F. (2008) Greater Plutonio project-Subsea flowline design and performance. In Proc. of Offshore Pipeline Technology Conference, pp. 1-36. Amsterdam, The Netherlands.

Kuo, M. \& Bolton, M. (2014) Shear tests on deep-ocean clay crust from the Gulf of Guinea. Géotechnique 64(4):249-257, http://dx.doi.org/10.1680/geot.13.P.020.

Li, X., Gaudin, C., Tian, Y. \& Cassidy, M. J. (2013) Effect of perforations on uplift capacity of skirted foundations on clay. Can Geotech J 51(3):322-331, http://dx.doi.org/10.1139/cgj-2013$\underline{0110 .}$

Lieng, J. \&Bjorgen, H. (1995) New flow-through mudmat design for Heidrun subsea structure. In Proc. of Offshore Technology Conference, Houston, TX, pp. 289-299. Offshore Technology Conference.

Martin, C. M., Dunne, H. P., Wallerand, R. \& Brown, N. (2015) Three-dimensional limit analysis of rectangular mudmat foundations. In Proc. of the $3^{\text {rd }}$ Int. Symp. on Front. in Offshore Geotech. (ISFOG 2015), Oslo, Norway, (eds Meyer, V.), pp. 789-794. London, UK: CRC Press.

Meyerhof, G. (1953) The bearing capacity of foundations under eccentric and inclined loads. In Proc. of the $3^{\text {rd }}$ International Conference on Soil Mechanics and Foundation Engineering, Zurich, Switzerland, vol. 1, pp. 440-445. Organizing Committee.

Murff, J. D., Aubeny, C. P. \& Yang, M. (2010) The effect of torsion on the sliding resistance of rectangular foundations. In Proc. of the $2^{\text {nd }}$ Int. Symp. on Front. in Offshore Geotech. (ISFOG 2010), Perth, Australia, (eds Gourvenec, S. and White, D.), pp. 439-443. London, UK: CRC Press.

Salençon, J. \& Pecker, A. (1995) Ultimate bearing capacity of shallow foundations under inclined and eccentric loads. I: Purely cohesive soil. Eur J Mech A. Solids 14(3):349375.

Shen, Z., Feng, X. \&Gourvenec, S. (2016) Undrained capacity of surface foundations with zerotension interface under planar VHM loading. Comput Geotech 73:47-57, http://dx.doi.org/10.1016/j.compgeo.2015.11.024.

Taiebat, H. \& Carter, J. (2000) Numerical studies of the bearing capacity of shallow foundations on cohesive soil subjected to combined loading. Géotechnique 50(4):409-418, http://dx.doi.org/10.1680/geot.2000.50.4.409.

Taiebat, H. \& Carter, J. (2002) Bearing capacity of strip and circular foundations on undrained clay subjected to eccentric loads. Géotechnique 52(1):61-64, http://dx.doi.org/10.1680/geot.2000.50.4.409. 
Taiebat, H. \& Carter, J. (2010) A failure surface for circular footings on cohesive soils. Géotechnique 60(4):265-273, http://dx.doi.org/10.1680/geot.7.00062.

Tapper, L., Martin, C., Byrne, B. \&Lehane, B. (2015) Undrained vertical bearing capacity of perforated offshore shallow foundations. In Proc. of the $3^{\text {rd }}$ Int. Symp. on Front. in Offshore Geotech. (ISFOG 2015), Oslo, Norway, (eds Meyer, V.), pp. 813-818. London, UK: CRC Press.

Ukritchon, B., Whittle, A. J. \& Sloan, S. W. (1998) Undrained limit analyses for combined loading of strip footings on clay. J Geotech Geoenviron Eng ASCE 124(3):265-276, http://dx.doi.org/10.1061/(ASCE)1090-0241(1998)124:3(265).

Wallerand, R., Stuyts, B., Blanc, M., Thorel, L. \& Brown, N. (2015) A Design Framework for Sliding Foundations: Centrifuge Testing and Numerical Modelling. In Proc. of Offshore Technology Conference, Houston, TX, paper OTC-25978-MS. Offshore Technology Conference.

White, D., Maconochie, A., Cheuk, C., Joray, D., Bolton, M. \&Springman, S. (2005) An investigation into the vertical bearing capacity of perforated mudmats. In Proc. of the $1^{\text {st }}$ Int. Symp. on Front. in Offshore Geotech. (ISFOG 2005), Perth, Australia, (eds Cassidy, M. and Gourvenec, S.), pp. 459-465. London, UK: Taylor and Francis. 


\section{Table captions}

Table 1: Values of $M_{\text {yult }} / A B s_{\mathrm{u} 0}$ and $M_{\text {xult }} / A L s_{\mathrm{u} 0}$ obtained from the FEA and EAM

\begin{tabular}{llllll}
\hline & & $\kappa=k B / s_{\mathrm{u} 0}$ & & \\
& 0 & 2 & 5 & 10 \\
\hline \multirow{3}{*}{ FEA(This study) } & $M_{\text {yult }} / A B s_{\mathrm{u} 0}$ & 0.71 & 0.88 & 1.06 & 1.23 \\
& Value of $v$ at $M_{\text {yult }}$ & 0.50 & 0.50 & 0.48 & 0.48 \\
& $M_{\text {xult }} / A L s_{\mathrm{u} 0}$ & 0.74 & 0.95 & 1.16 & 1.45 \\
& Value of $v$ at $M_{\text {xult }}$ & 0.52 & 0.50 & 0.52 & 0.50 \\
& $M_{\text {yult }} / A B s_{\mathrm{u} 0}$ & 0.67 & 0.83 & 1.10 & 1.24 \\
& Value of $v$ at $M_{\text {yult }}$ & 0.49 & 0.48 & 0.48 & 0.47 \\
& $M_{\text {xult }} / A L s_{\mathrm{u} 0}$ & 0.76 & 0.95 & 1.16 & 1.44 \\
& Value of $v$ at $M_{\text {xult }}$ & 0.54 & 0.50 & 0.50 & 0.50 \\
\hline
\end{tabular}

Table 2: Input data for example applications

\begin{tabular}{llll}
\hline Parameter & Values & Parameter & Values \\
\hline Width, B: $\mathrm{m}$ & 5 & Horizontal load, $\mathrm{H}_{\mathrm{x}}: \mathrm{kN}$ & $80(20)^{1}$ \\
Length, L: $\mathrm{m}$ & 10 & Horizontal load, $\mathrm{H}_{\mathrm{y}}: \mathrm{kN}$ & 100 \\
Soil strength, $\mathrm{s}_{\mathrm{u} 0}: \mathrm{kPa}$ & 4.8 & Moment, $\mathrm{M}_{\mathrm{x}}: \mathrm{kNm}$ & 400 \\
Strength gradient, $\mathrm{k}: \mathrm{kPa} / \mathrm{m}$ & 1.5 & Moment, $\mathrm{M}_{\mathrm{y}}: \mathrm{kNm}$ & $480(120)$ \\
Vertical load, $\mathrm{V}: \mathrm{kN}$ & 400 & Torsion, $\mathrm{T}: \mathrm{kNm}$ & 240 \\
\hline
\end{tabular}

${ }^{1}$ : The bracketed value is only presented for Example 2 if the design load is different from that for Example 1.

Table 3: Uniaxial capacity and load mobilisation for Example 1

\begin{tabular}{llll}
\hline Capacity & Value & Mobilisation & Value \\
\hline $\mathrm{V}_{\text {ult: }} \mathrm{kN}$ & 1758 & $\mathrm{~V} / \mathrm{V}_{\text {ult }}$ & 0.23 \\
$\mathrm{H}_{\text {xult }}: \mathrm{kN}$ & 240 & $\mathrm{H}_{\mathrm{x}} / \mathrm{H}_{\text {xult }}$ & 0.33 \\
$\mathrm{H}_{\text {yult }}: \mathrm{kN}$ & 240 & $\mathrm{H}_{\mathrm{y}} / \mathrm{H}_{\text {yult }}$ & 0.42 \\
$\mathrm{M}_{\text {yult: }} \mathrm{kNm}$ & 1010 & $\mathrm{M}_{\mathrm{y}} / \mathrm{M}_{\text {yult }}$ & 0.48 \\
$\mathrm{M}_{\text {xult: }}: \mathrm{kNm}$ & 2134 & $\mathrm{M}_{\mathrm{x}} / \mathrm{M}_{\text {xult }}$ & 0.19 \\
\hline
\end{tabular}




\begin{tabular}{|c|c|c|c|}
\hline $\mathrm{T}_{\text {ult: }} \mathrm{kNm}$ & 713 & $\mathrm{~T} / \mathrm{T}_{\text {ult }}$ & 0.34 \\
\hline $\mathrm{H}_{\max _{-} 1}: \mathrm{kN}$ & 240 & $\mathrm{H} / \mathrm{H}_{\text {max_} \_1}$ & 0.53 \\
\hline $\mathrm{M}_{\text {max_1 }_{1}: \mathrm{kNm}}$ & 843 & $\mathrm{M} / \mathrm{M}_{\text {max } \_1_{1}}$ & 0.74 \\
\hline $\mathrm{T}_{\max \_1}: \mathrm{kNm}$ & 713 & $\mathrm{~T} / \mathrm{T}_{\max \_1}$ & 0.34 \\
\hline $\mathrm{H}_{\max \_2}: \mathrm{kN}$ & 218 & $\mathrm{H} / \mathrm{H}_{\text {max_2 }}$ & 0.59 \\
\hline $\mathrm{M}_{\max \_2}: \mathrm{kNm}$ & 778 & $\mathrm{M} / \mathrm{M}_{\text {max } \_2}$ & 0.80 \\
\hline
\end{tabular}




\section{Figure captions}

Figure 1: V-M-H failure envelopes for rectangular foundations on soil with uniform strength with depth $(B / L=0.5)$

Figure 2: General loading for a rectangular mudmat and linearly varying soil strength

Figure 3: Half view through the central plane of the fully three-dimensional finite element mesh for a rectangular mudmat

Figure 4: Example of failure envelope and the load-displacement curves for selected load paths

Figure 5: Vertical bearing capacity factor for rectangular foundations $(B / L=0.5)$

Figure 6: V-H failure envelopes from FEA with ZTI and UTI and from the traditional method

Figure 7: Normalised V-H failure envelopes for mudmats with ZTI

Figure 8: V-M failure envelopes from FEA with ZTI and UTI and from the traditional effective area method (EAM)

Figure 9: Normalised V-M failure envelopes for mudmats and the parabolic function

Figure 10: Failure envelopes for mudmats under combined V-T loading

Figure 11: Failure envelopes for mudmats under biaxial horizontal loading

Figure 12: Failure envelopes for mudmats under biaxial moment loading

Figure 13: Example of failure envelopes for mudmats under V-M-H loading

Figure 14: Normalised failure envelopes for mudmats under V-M-H loading

Figure 15: Normalised failure envelopes for mudmats under combined H-T loading

Figure 16: Comparison of T-M failure envelopes between mudmats with ZTI and UTI

Figure 17: Normalised T-M failure envelopes for mudmats with ZTI

Figure 18: Failure envelopes for mudmats under V-H-M-T loading

Figure 19: Factored failure envelopes and design loading for example applications 


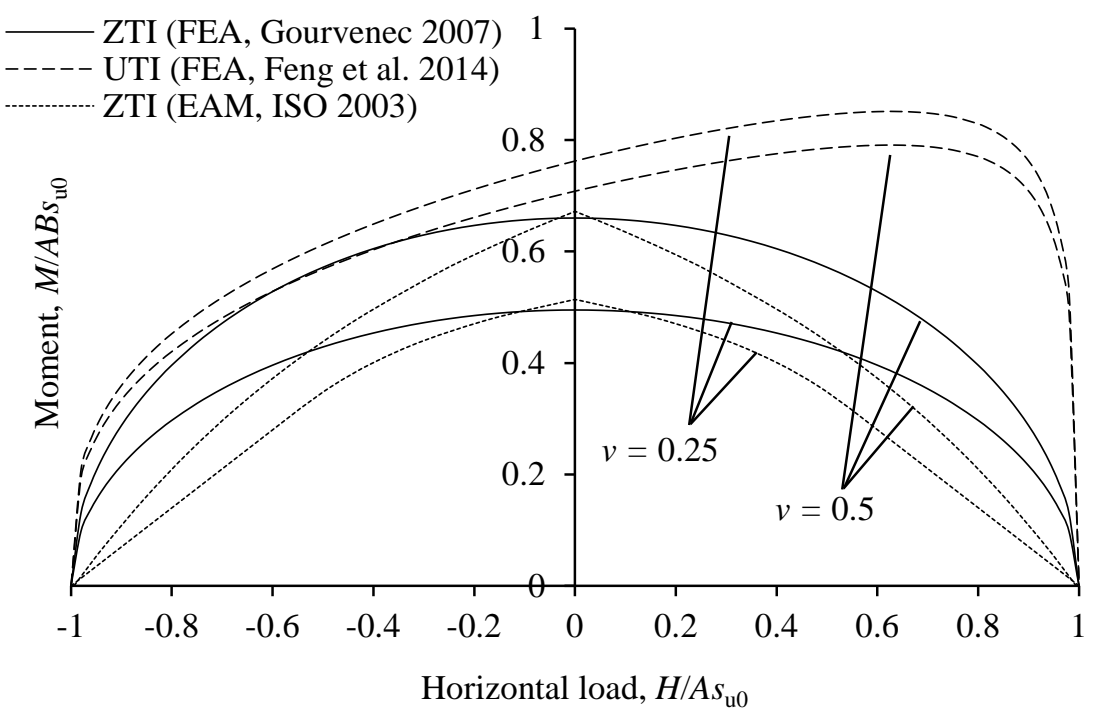

Figure 1: V-M-H failure envelopes for rectangular foundations on soil with uniform strength with depth $(B / L=0.5)$

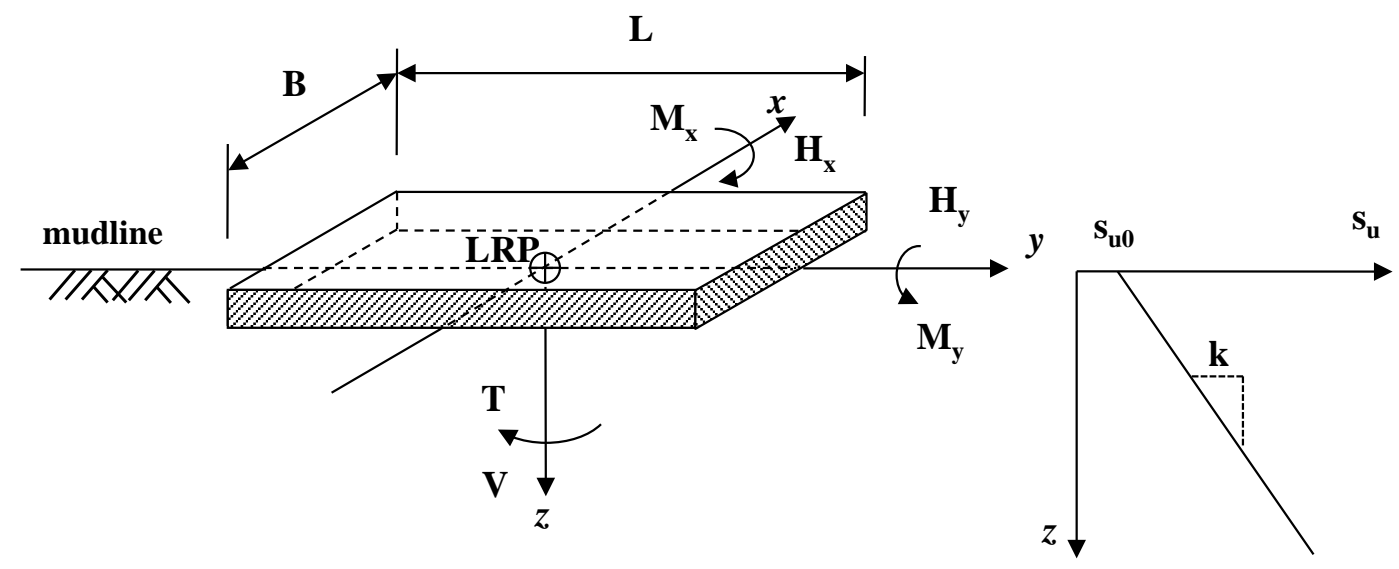

(a) Sign convention and nomenclature for $\mathrm{V}-\mathrm{H}^{2}-\mathrm{M}^{2}-\mathrm{T}$ loading and linearly varying soil strength profile

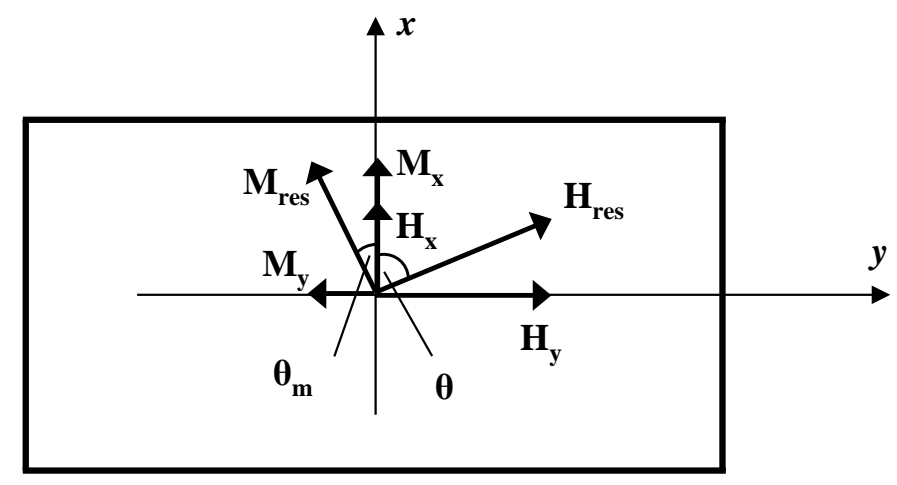

(b) Resultant horizontal and moment loading

Figure 2: General loading for a rectangular mudmat and linearly varying soil strength 


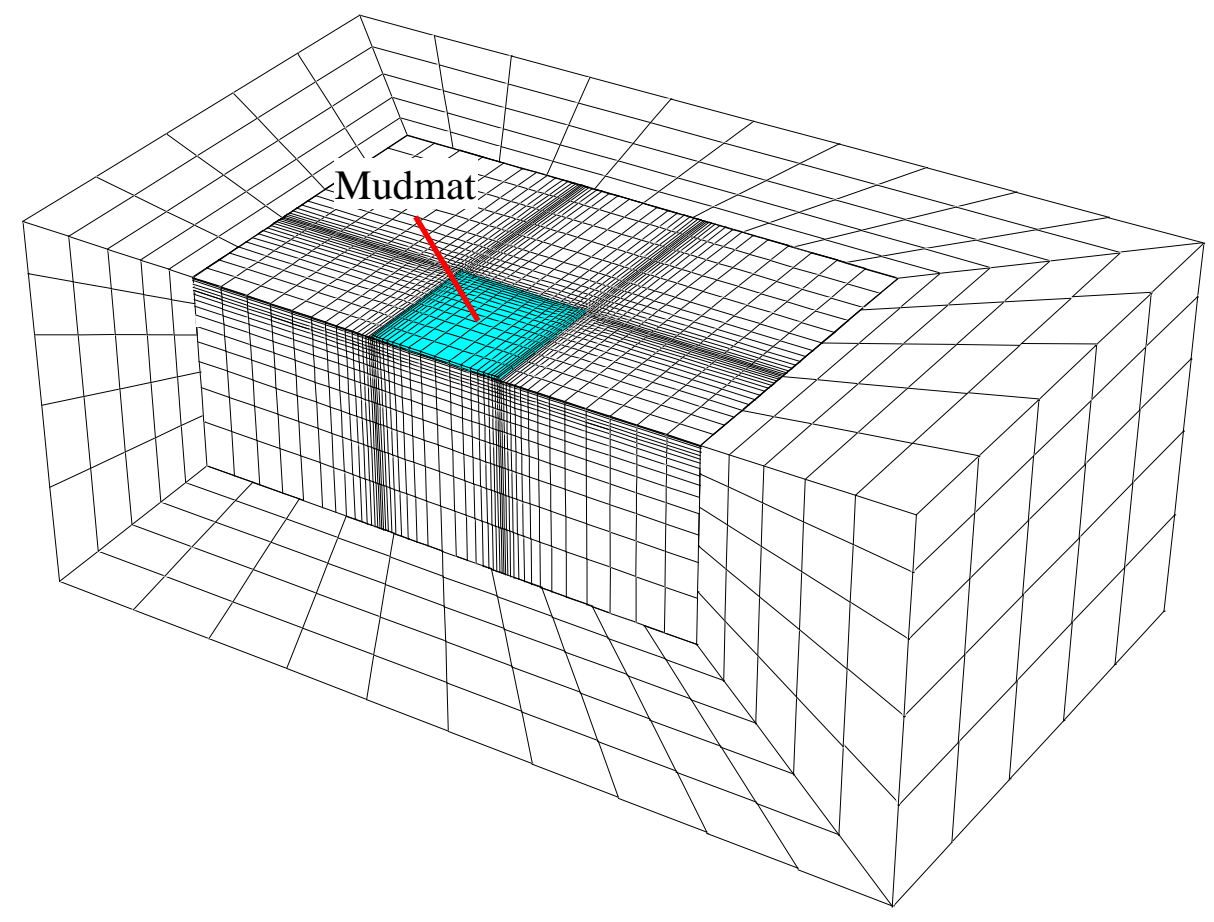

Figure 3: Half view through the central plane of the fully three-dimensional finite element mesh for a rectangular mudmat

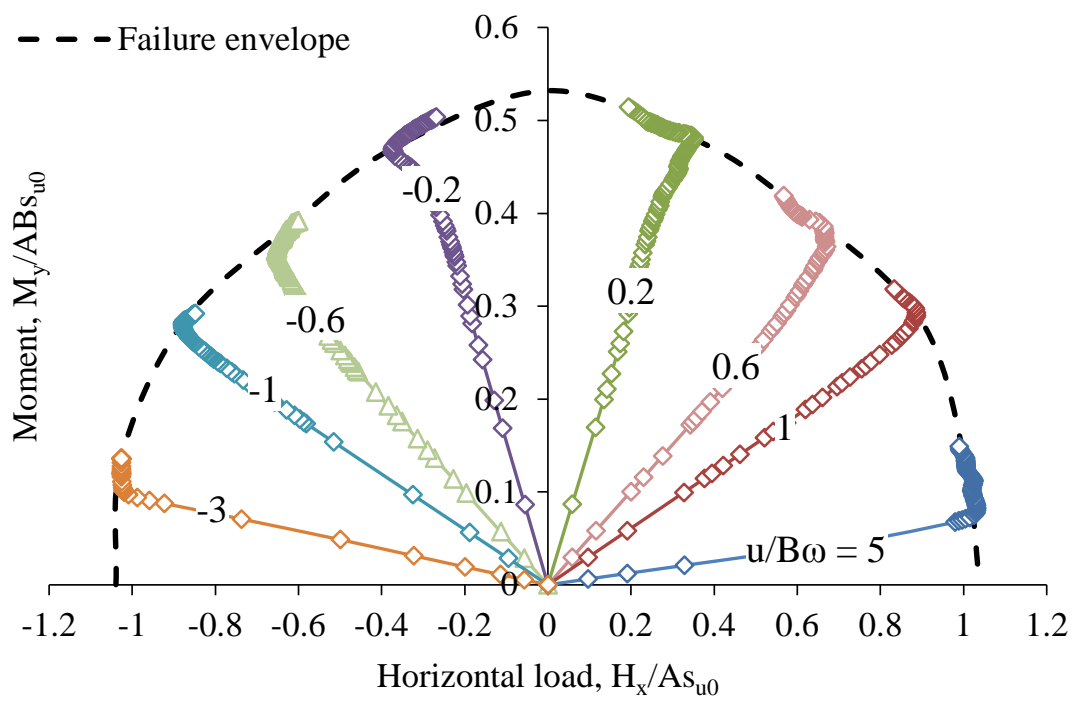

a) $\mathrm{H}_{\mathrm{x}}-\mathrm{M}_{\mathrm{y}}$ failure envelope and load paths $(\kappa=0 ; \mathrm{v}=0.25)$ 


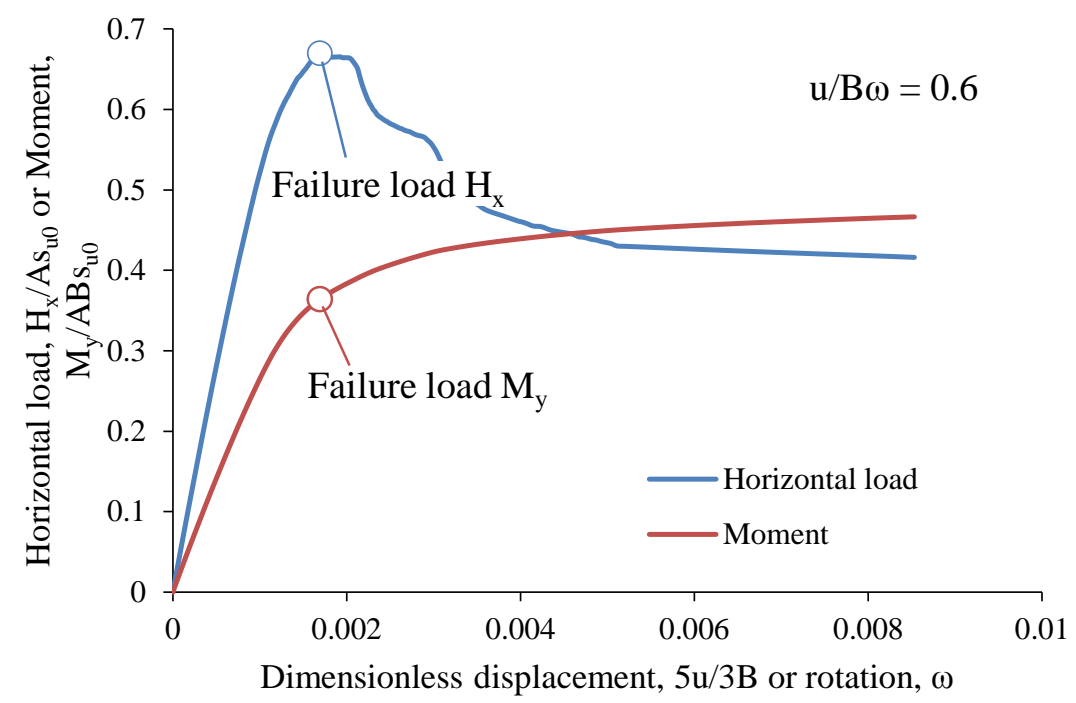

b) Load-displacement curve for $\mathrm{u} / \mathrm{B} \omega=0.6$

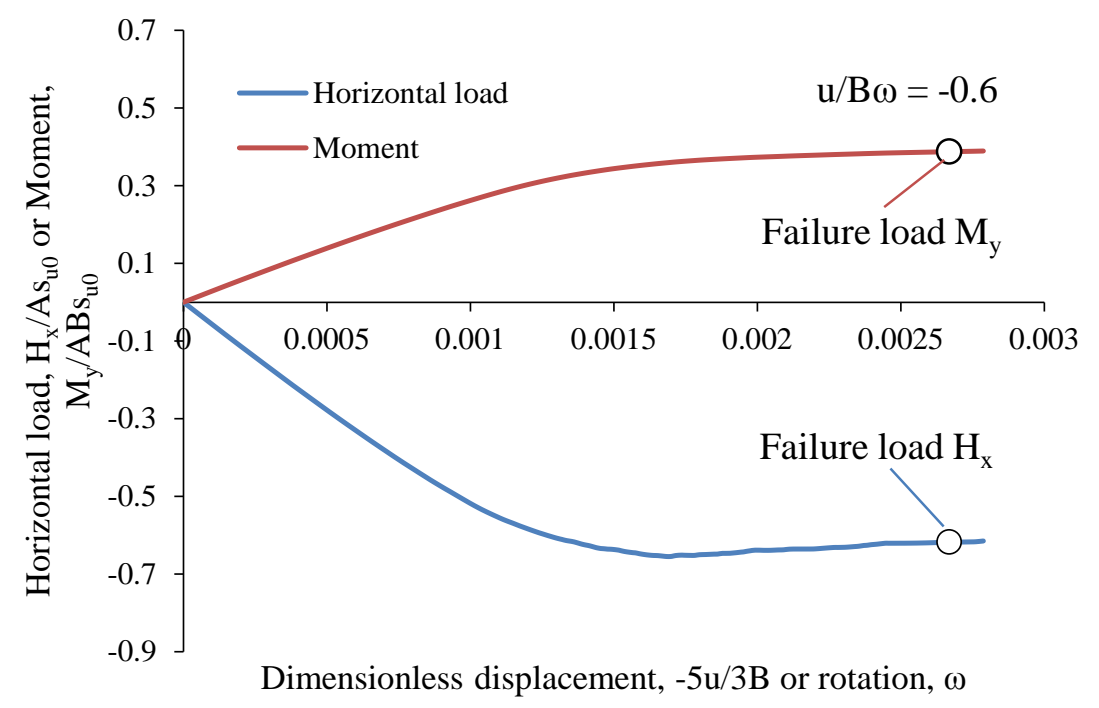

c) Load-displacement curve for $\mathrm{u} / \mathrm{B} \omega=-0.6$

Figure 4: Example of failure envelope and the load-displacement curves for selected load paths 


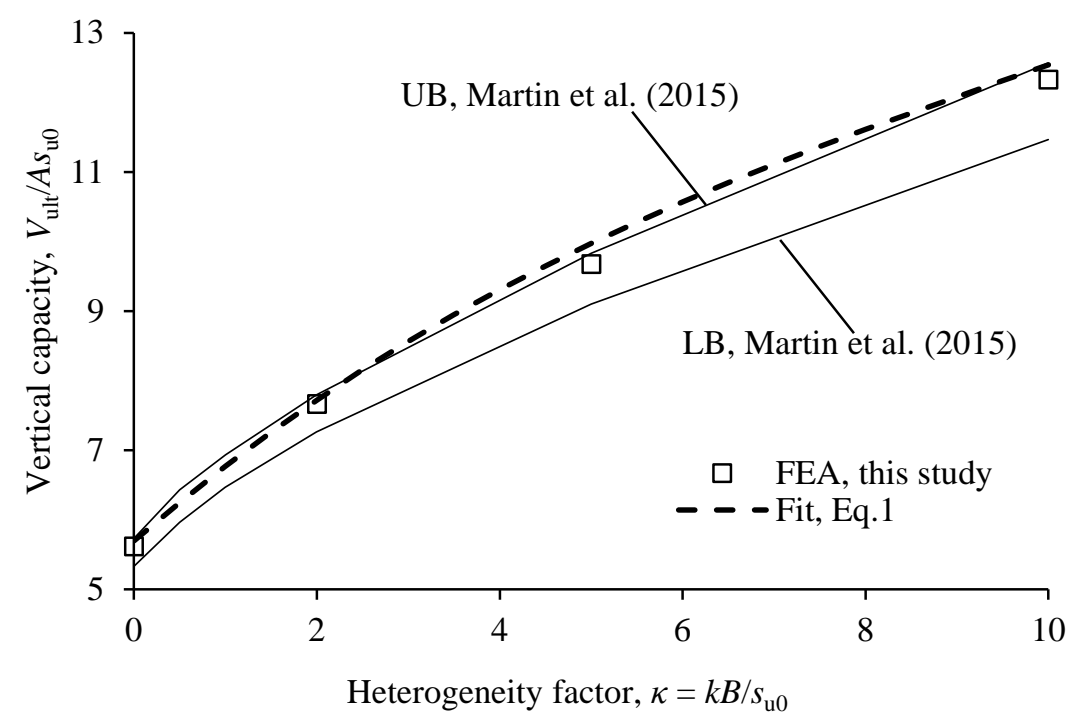

Figure 5: Vertical bearing capacity factor for rectangular foundations $(B / L=0.5)$

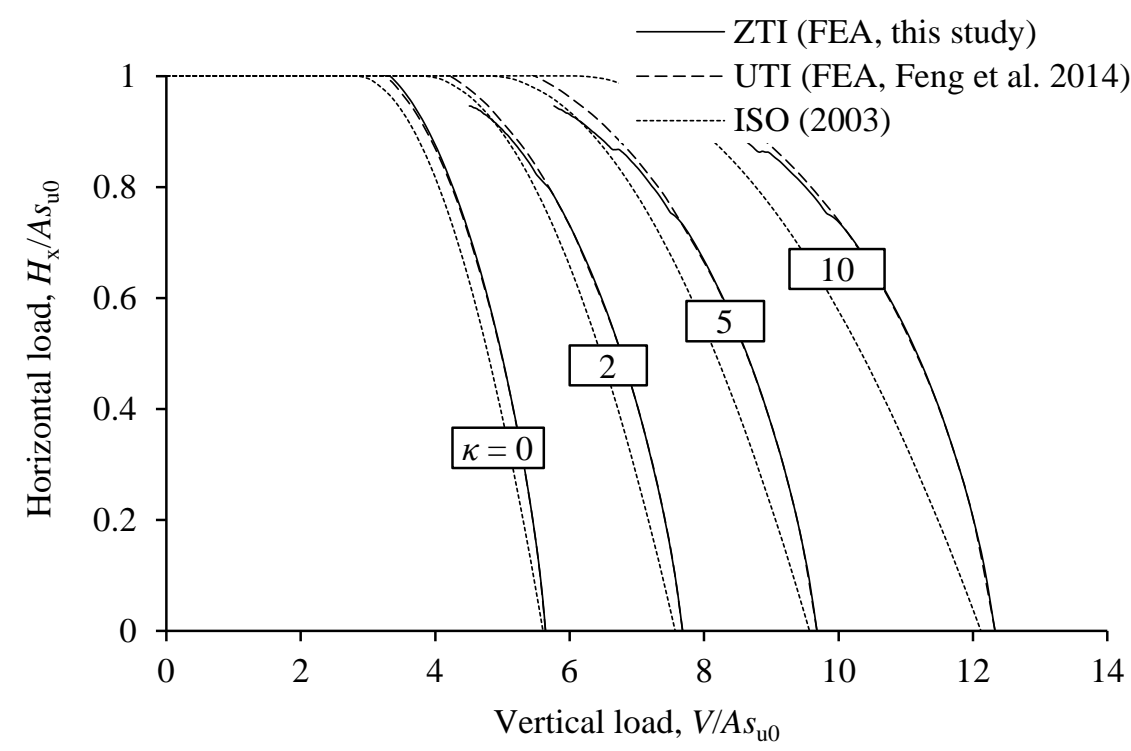

a) V-H $\mathrm{H}_{\mathrm{x}}$ loading plane 


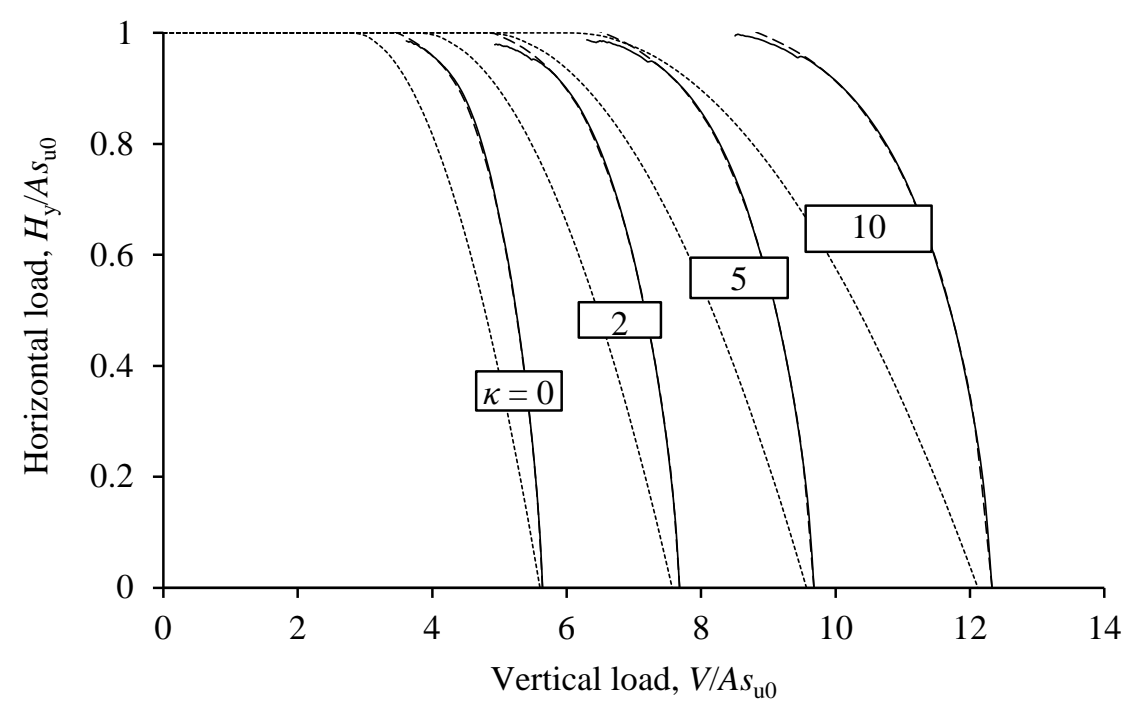

b) V-Hy loading plane

Figure 6: V-H failure envelopes from FEA with ZTI and UTI and from the traditional method

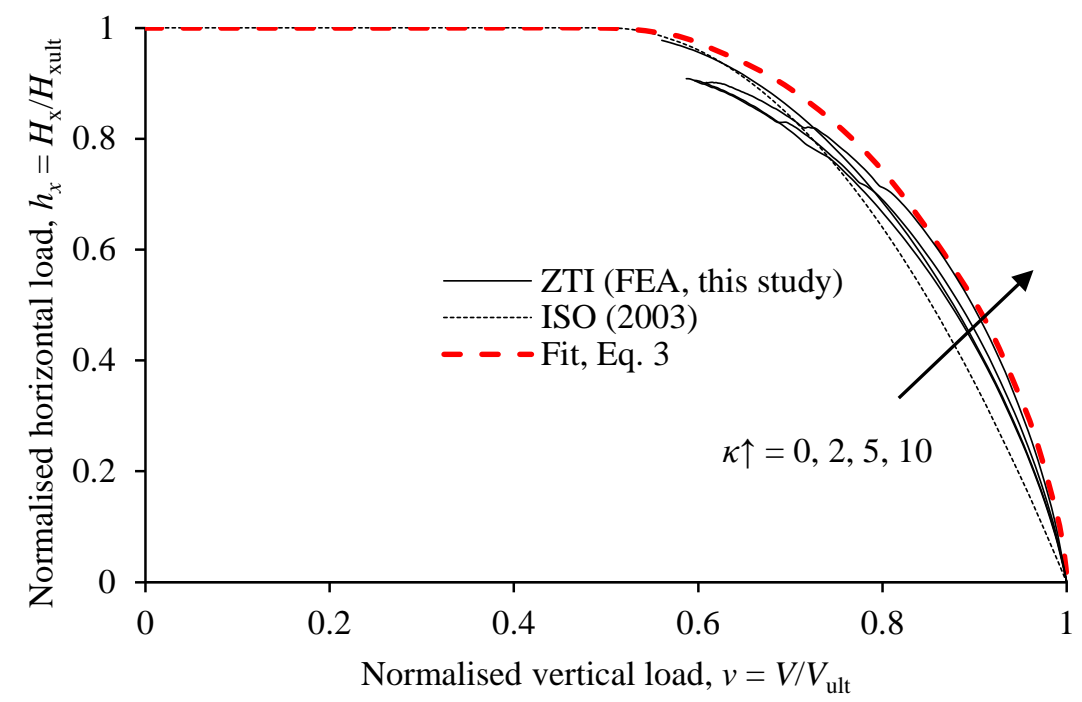

a) $v-h_{x}$ 


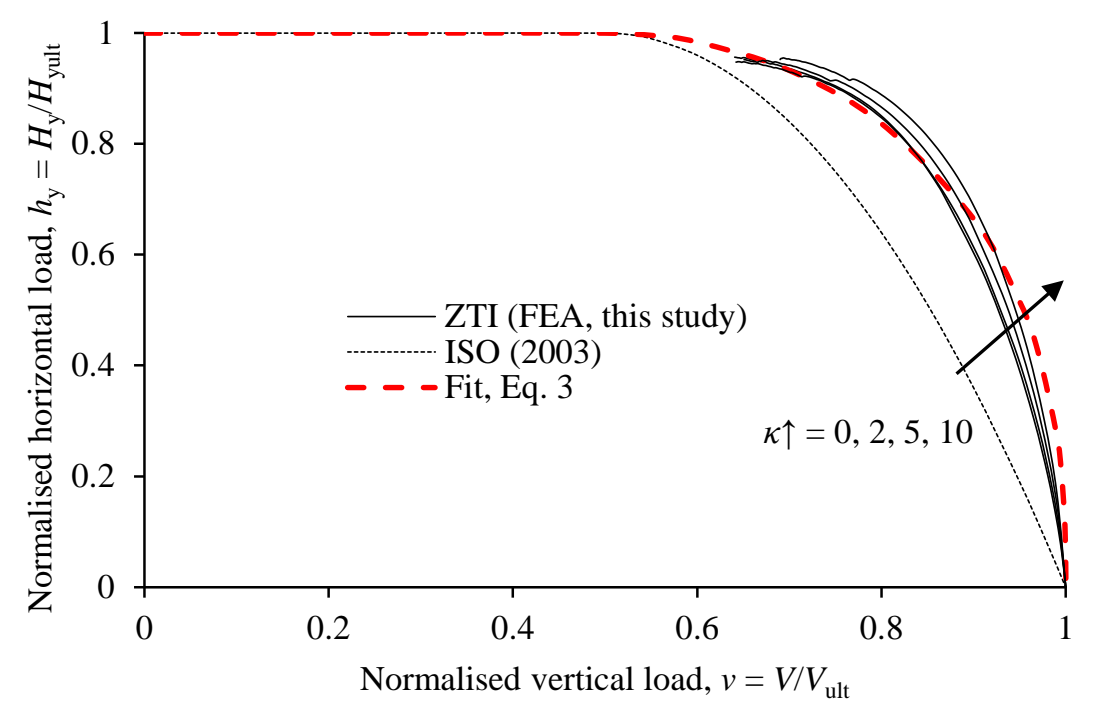

b) v-hy

Figure 7: Normalised V-H failure envelopes for mudmats with ZTI

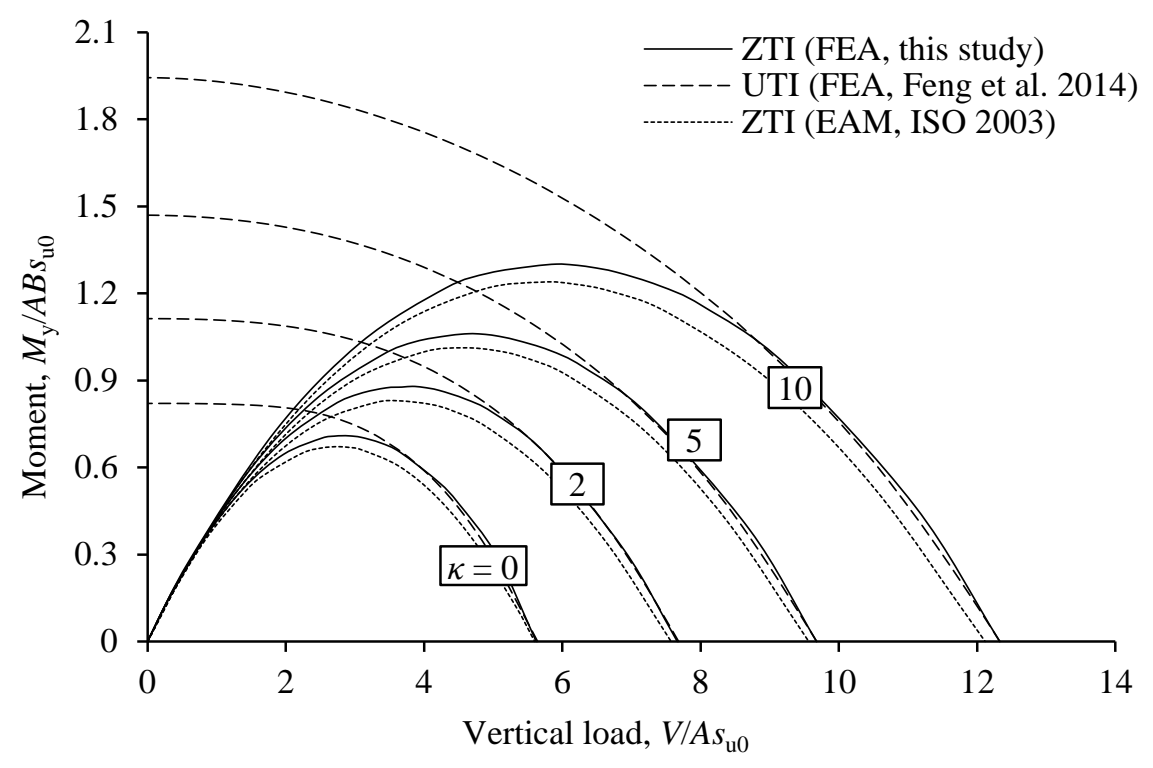

a) V-My loading plane 


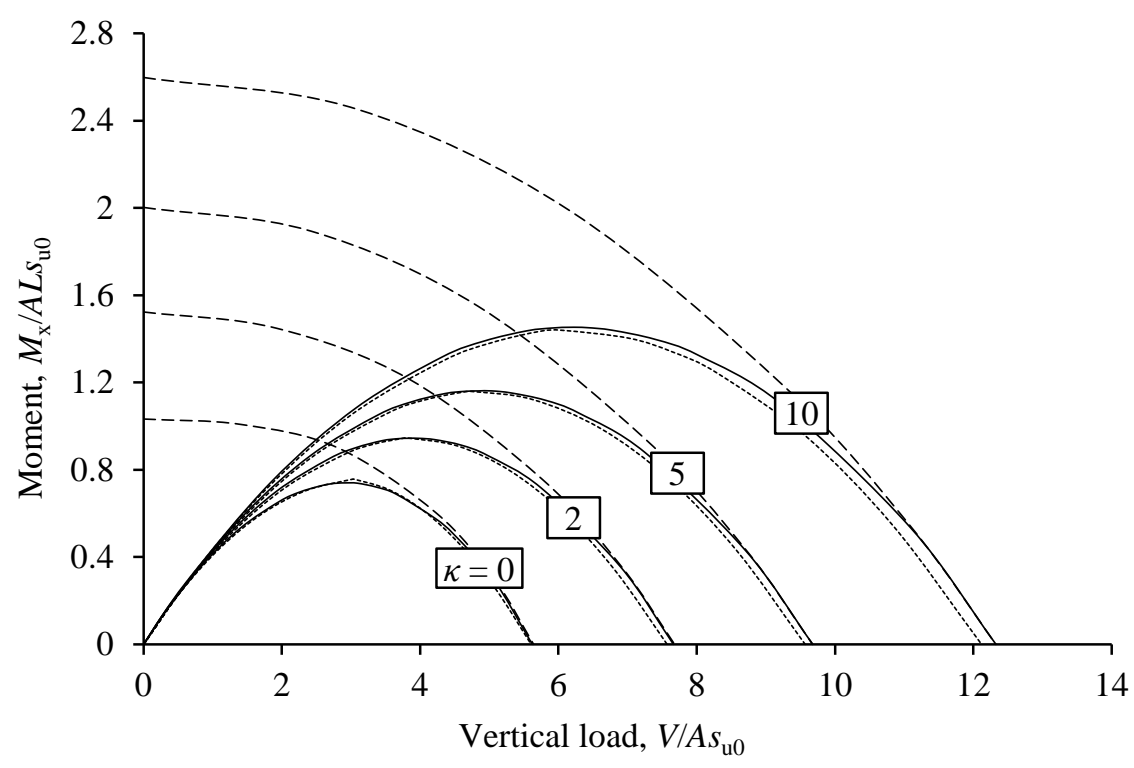

b) V-M $\mathrm{M}_{\mathrm{x}}$ loading plane

Figure 8: V-M failure envelopes from FEA with ZTI and UTI and from the traditional effective area method (EAM)

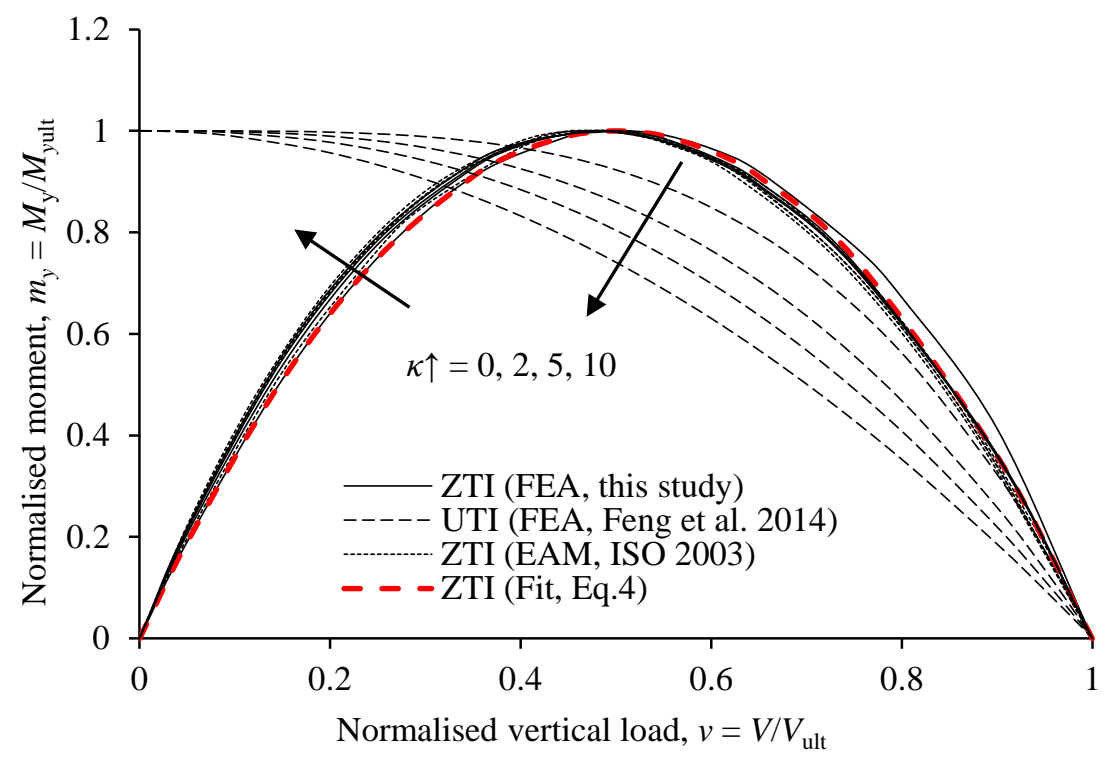

a) v-my 


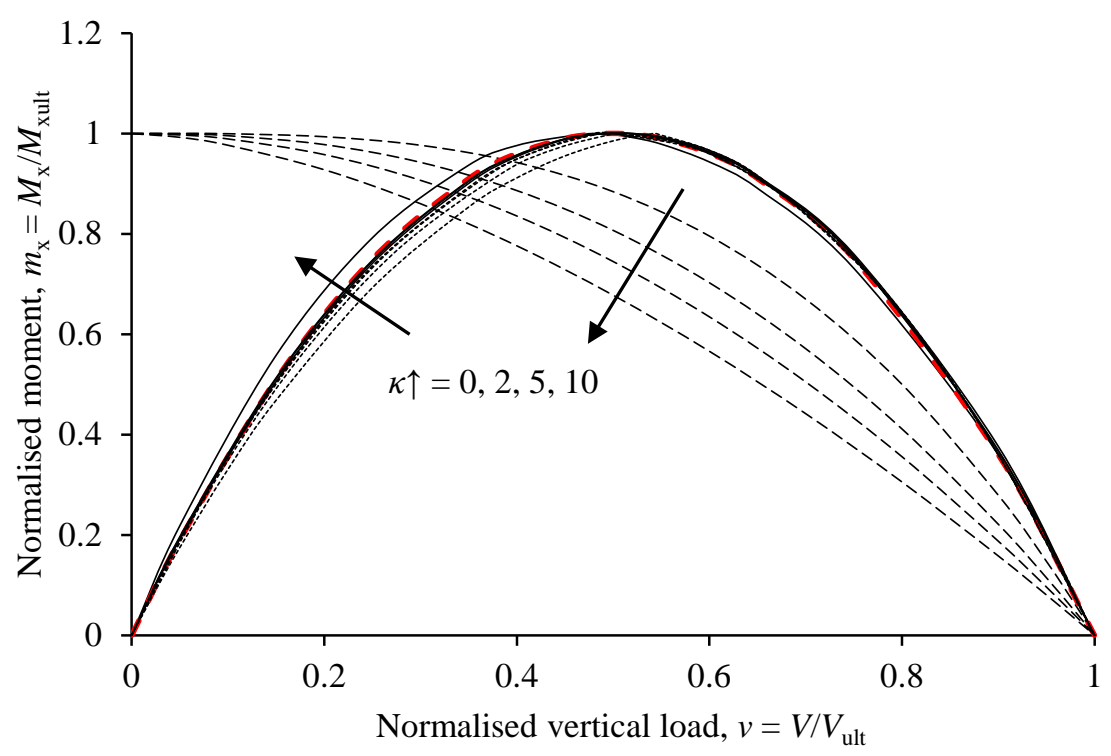

b) v-mx

Figure 9: Normalised V-M failure envelopes for mudmats and the parabolic function

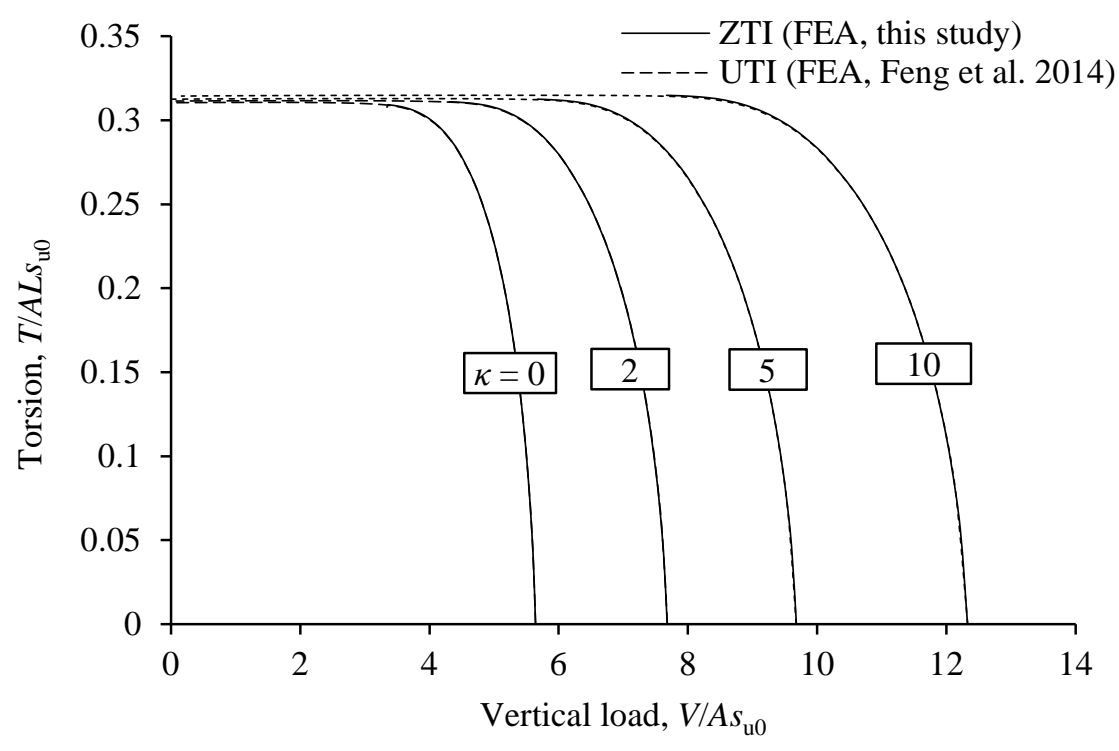

a) Dimensionless 


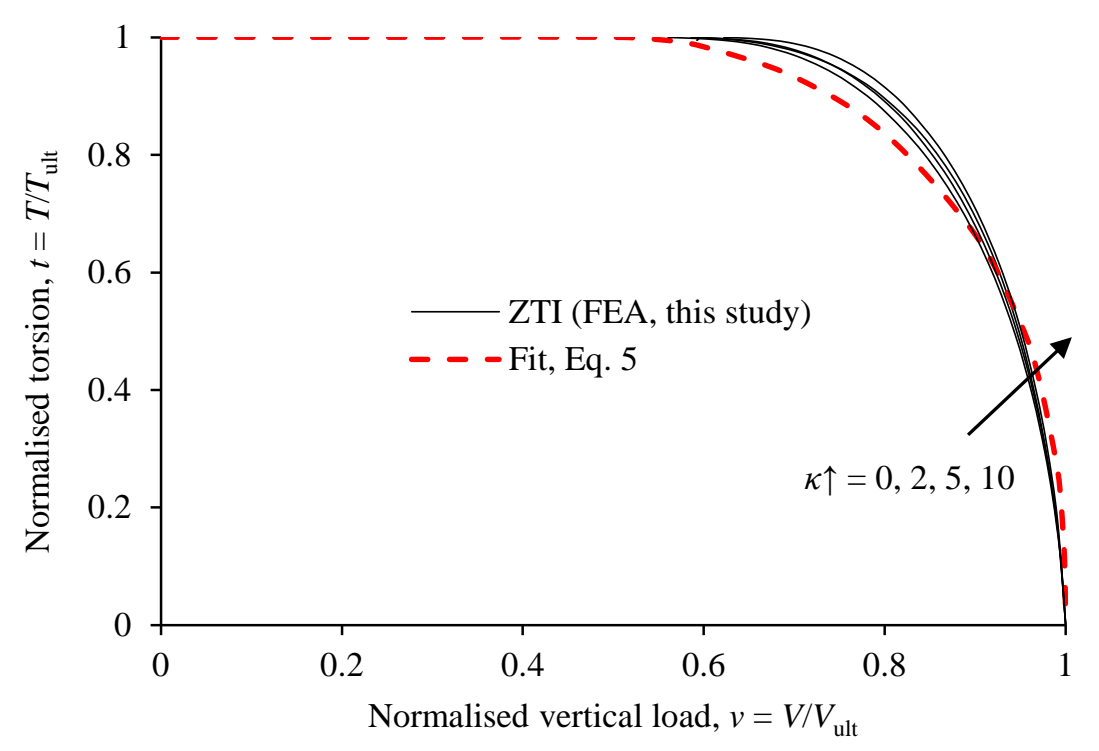

b) Normalised

Figure 10: Failure envelopes for mudmats under combined V-T loading

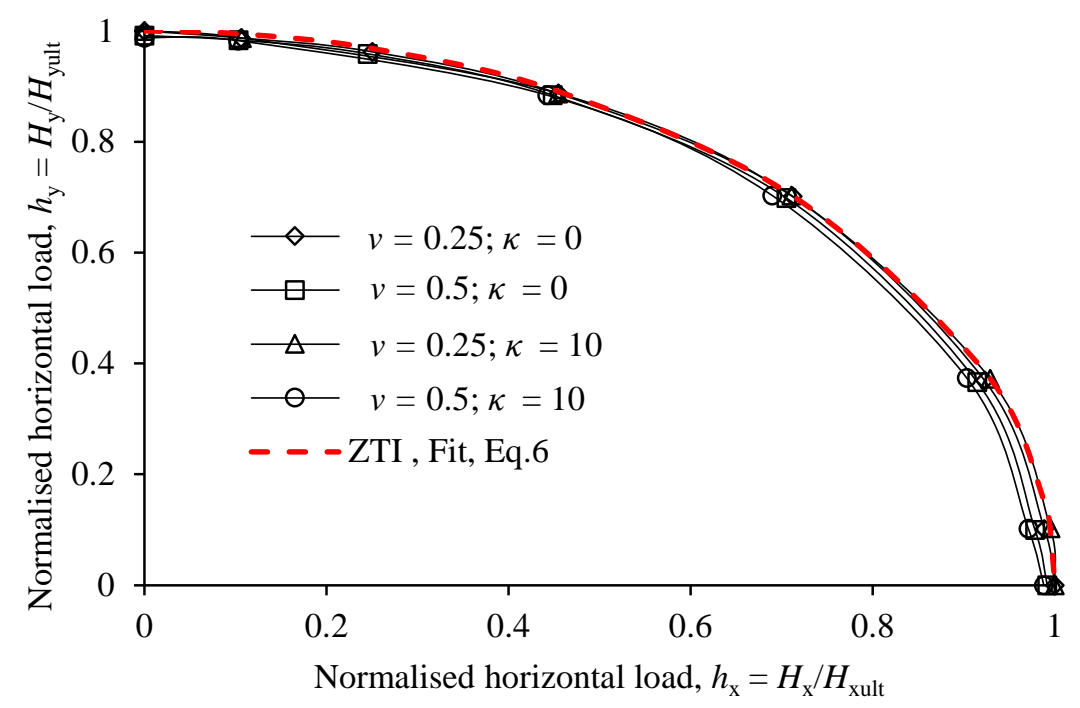

Figure 11: Failure envelopes for mudmats under biaxial horizontal loading 


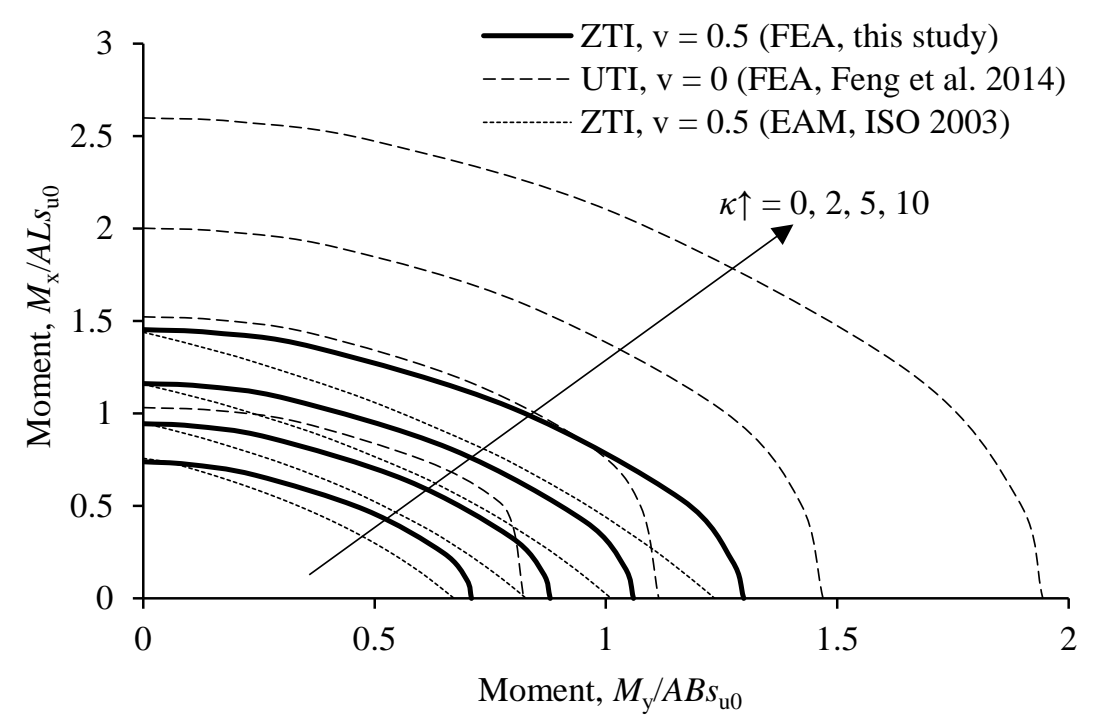

a) Dimensionless

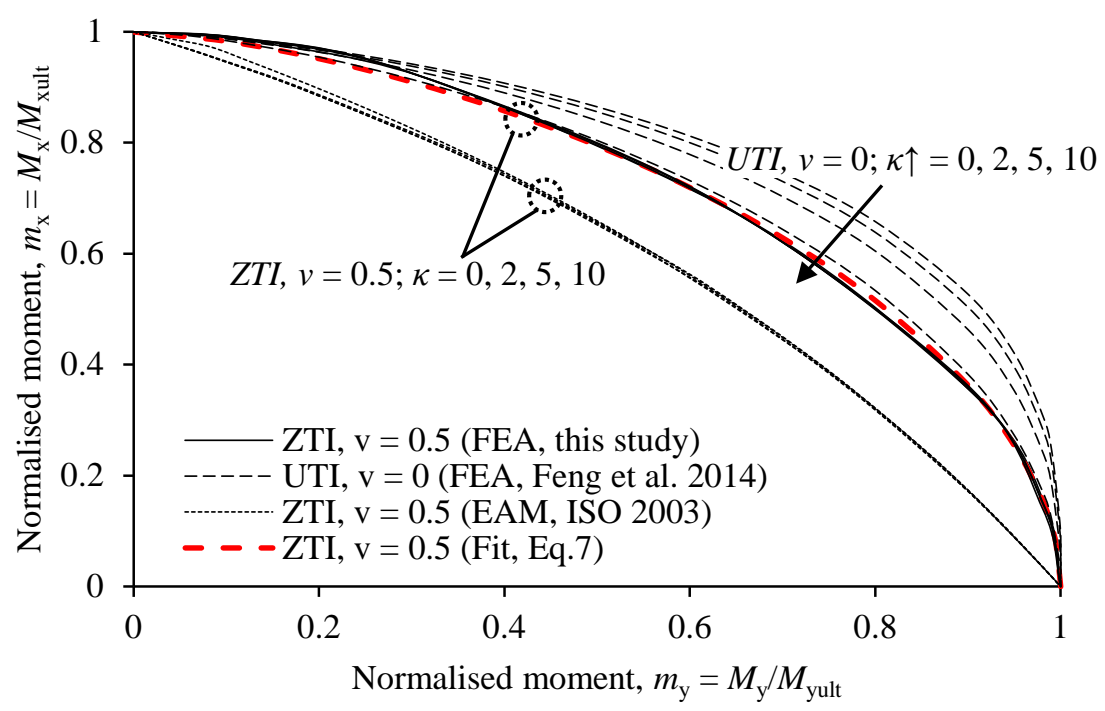

b) Normalised

Figure 12: Failure envelopes for mudmats under biaxial moment loading 


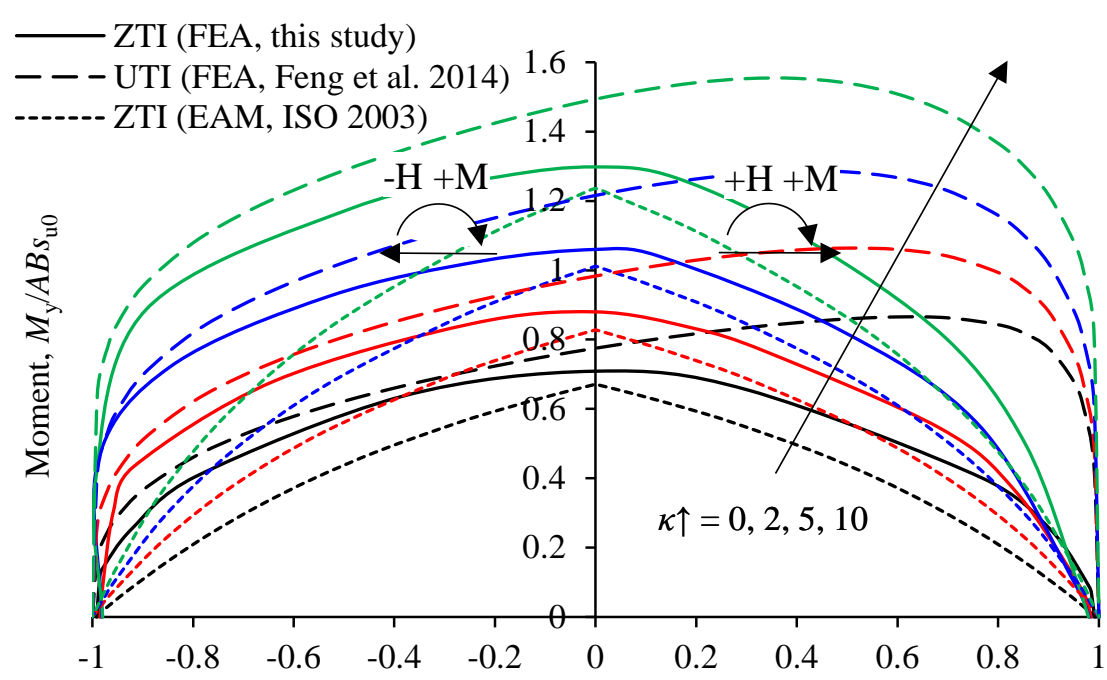

Horizontal load, $H_{\mathrm{x}} / A s_{\mathrm{u} 0}$

Figure 13: Example of failure envelopes for mudmats under V-M-H loading

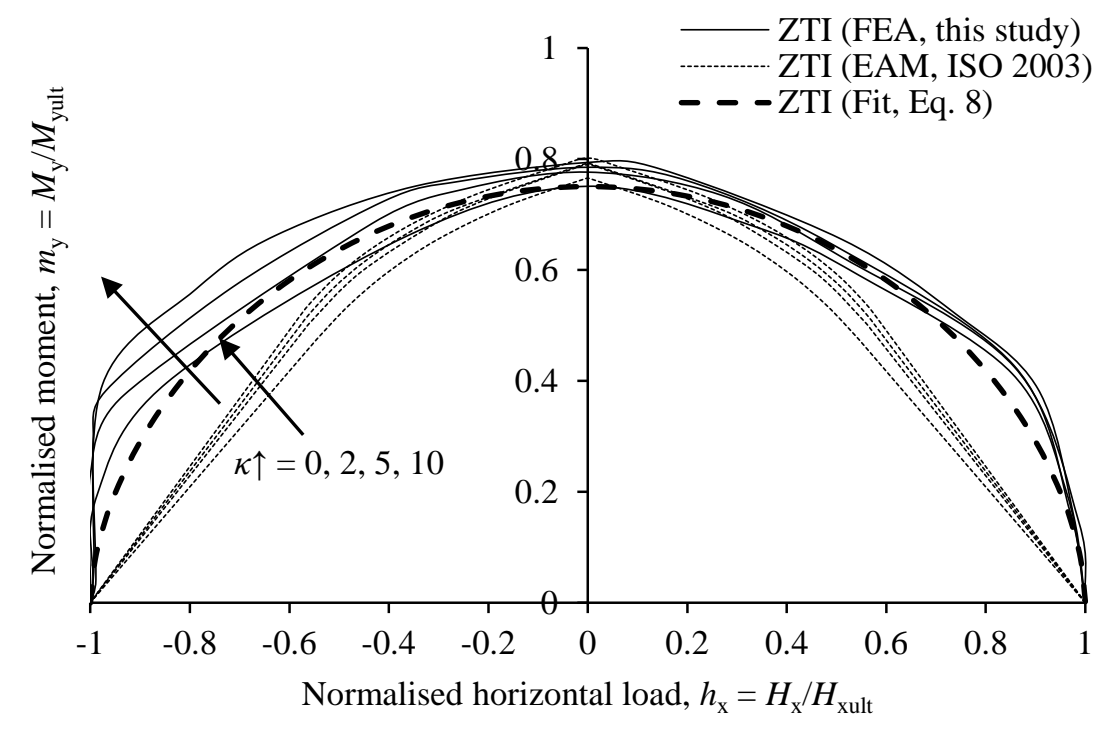

a) $\mathrm{v}=0.25, \theta=0^{\circ}, \theta_{\mathrm{m}}=90^{\circ}$ 


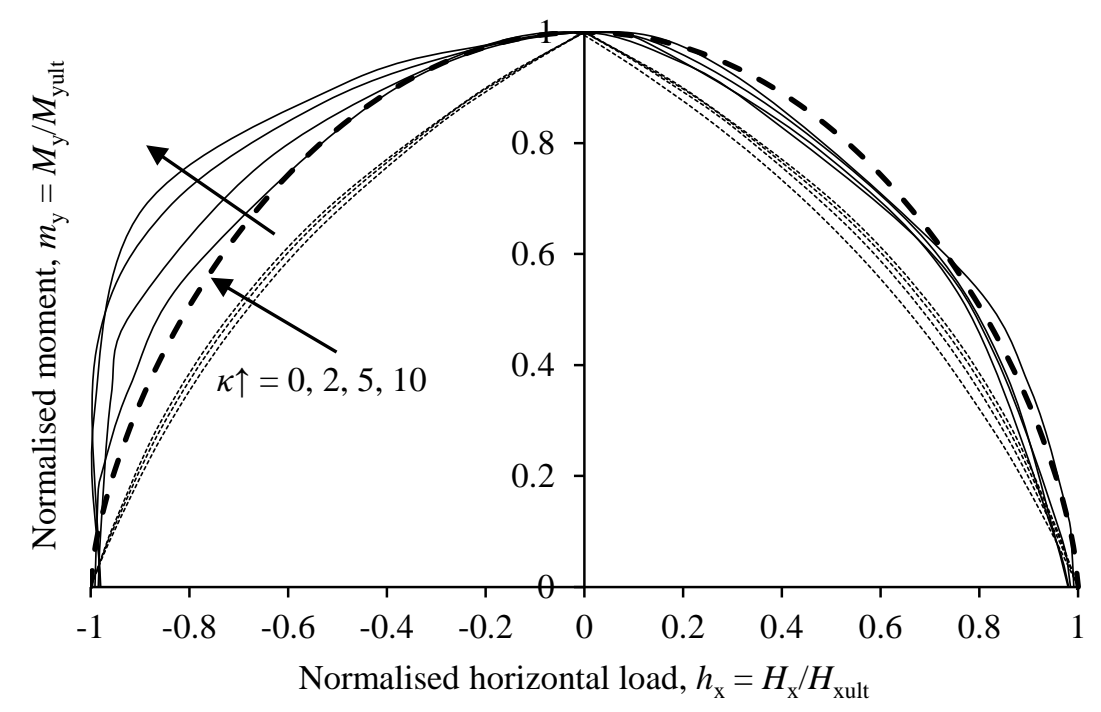

b) $\mathrm{v}=0.5, \theta=0^{\circ}, \theta_{\mathrm{m}}=90^{\circ}$

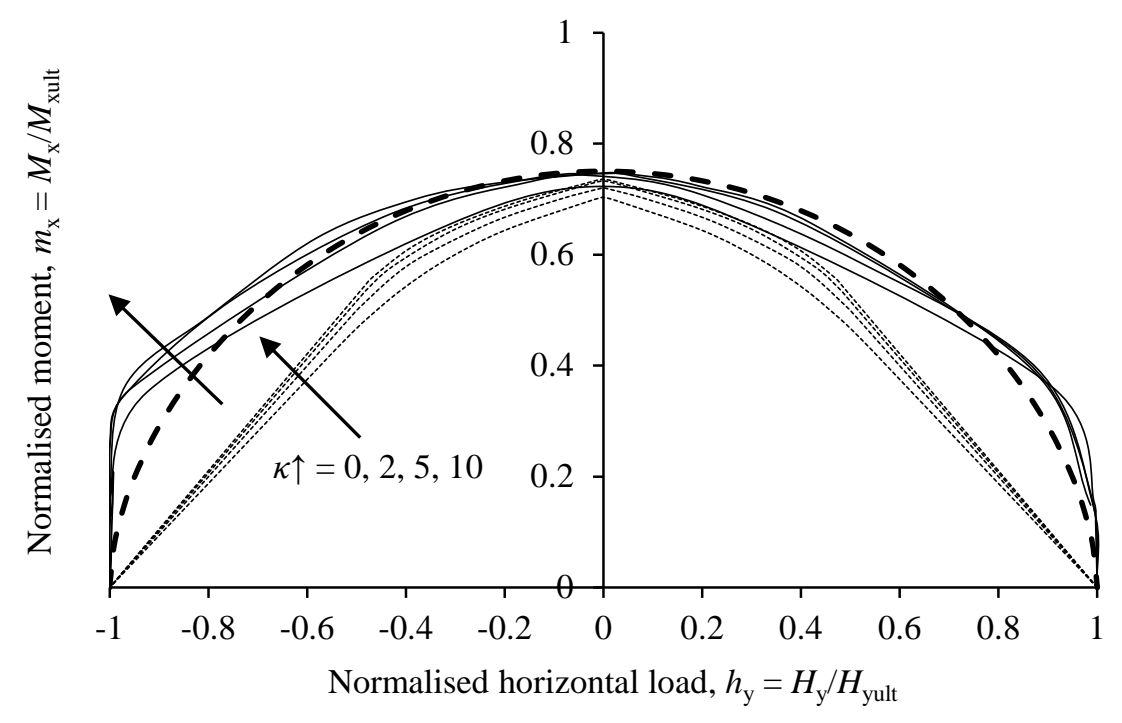

c) $\mathrm{v}=0.25, \theta=90^{\circ}, \theta_{\mathrm{m}}=0^{\circ}$ 


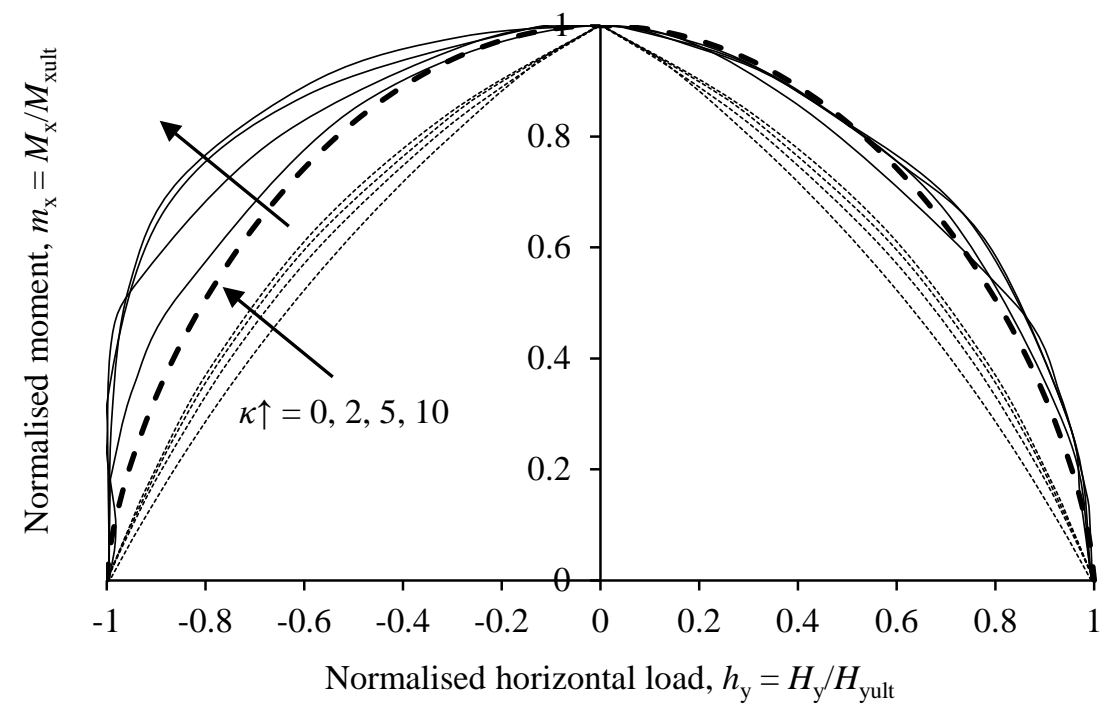

d) $\mathrm{v}=0.5, \theta=90^{\circ}, \theta_{\mathrm{m}}=0^{\circ}$

Figure 14: Normalised failure envelopes for mudmats under V-M-H loading

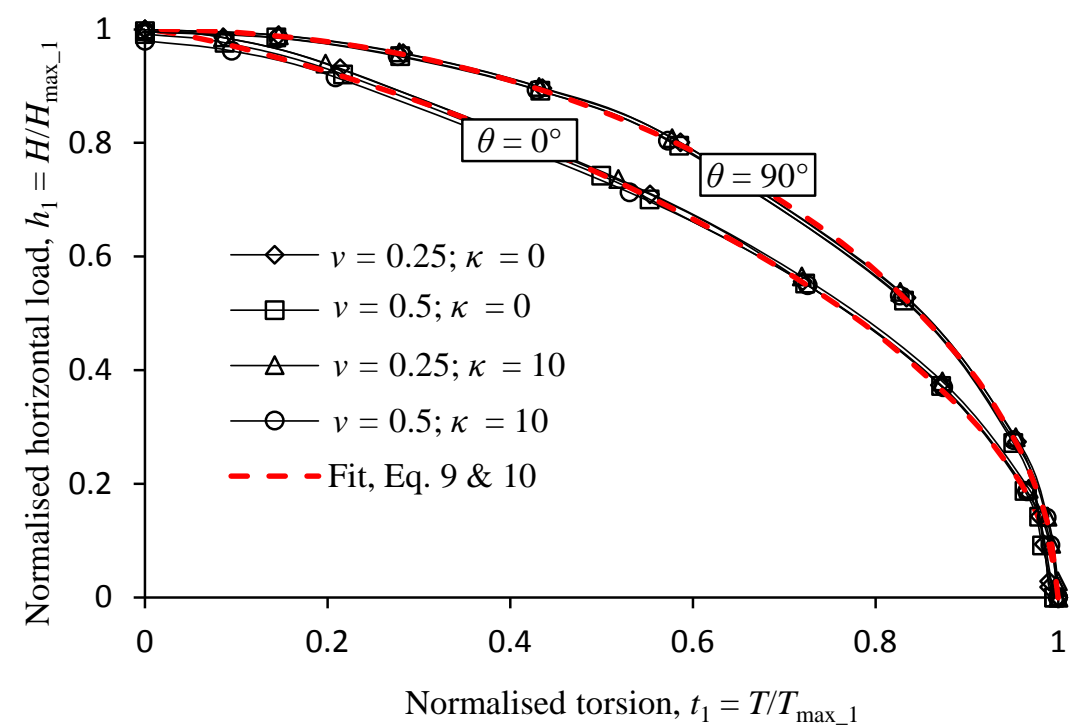

Figure 15: Normalised failure envelopes for mudmats under combined H-T loading 


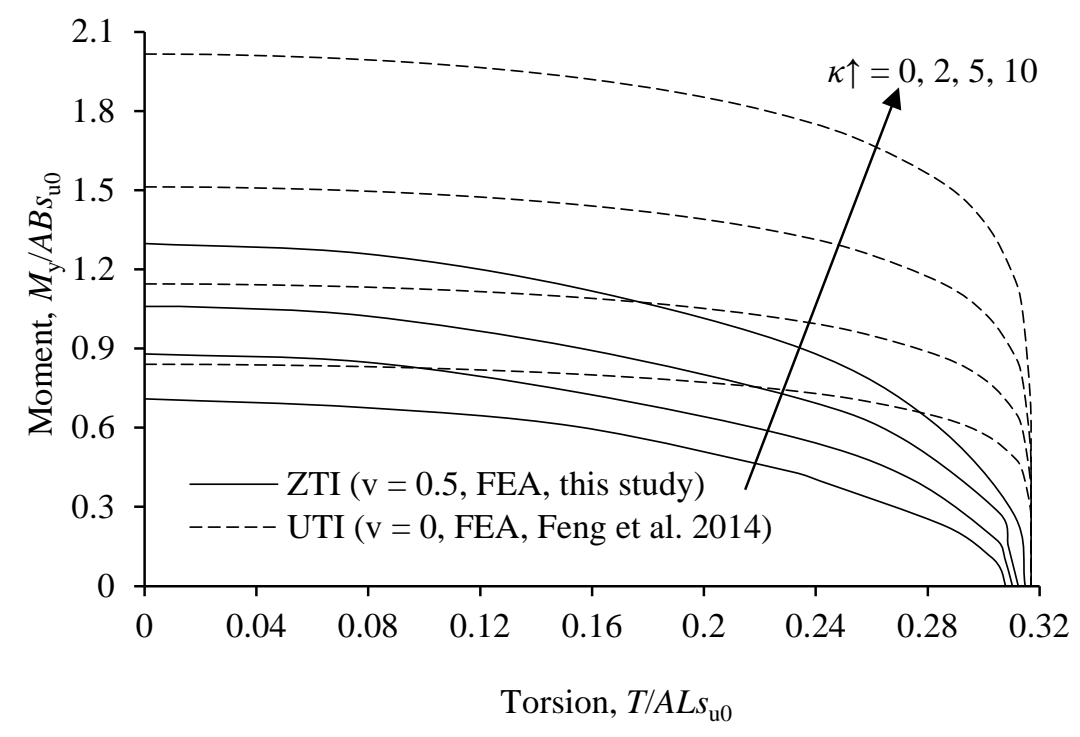

Figure 16: Comparison of T-M failure envelopes between mudmats with ZTI and UTI

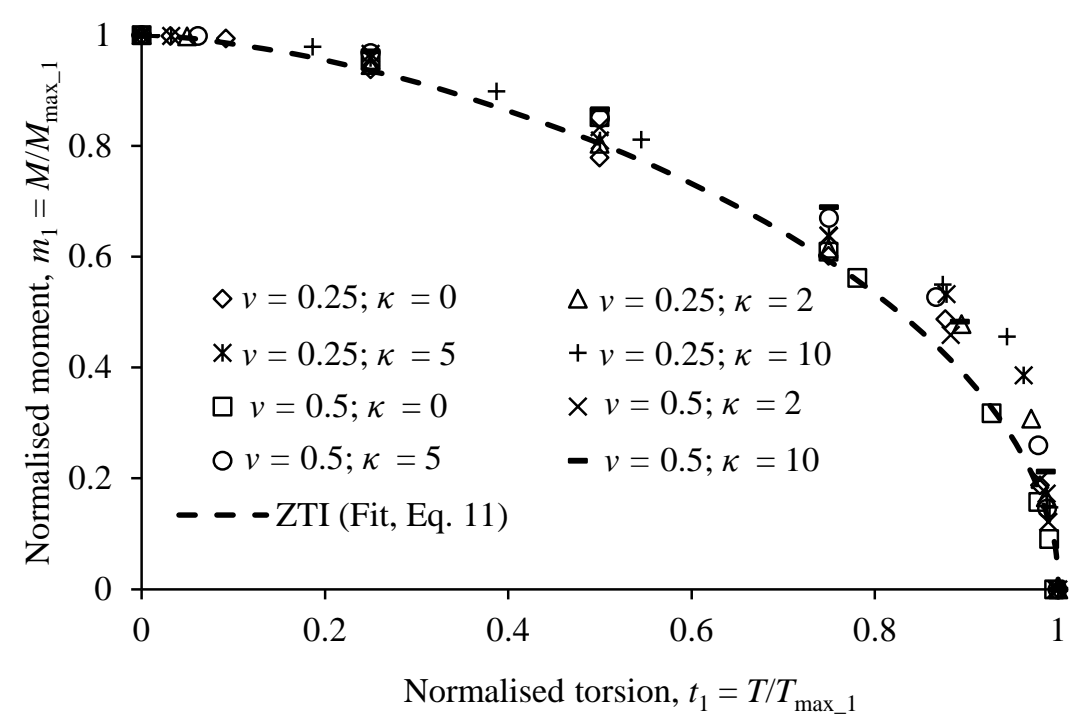

a) $\mathrm{T}-\mathrm{M}_{\mathrm{y}}$ loading $\left(\theta_{\mathrm{m}}=90^{\circ}\right)$ 


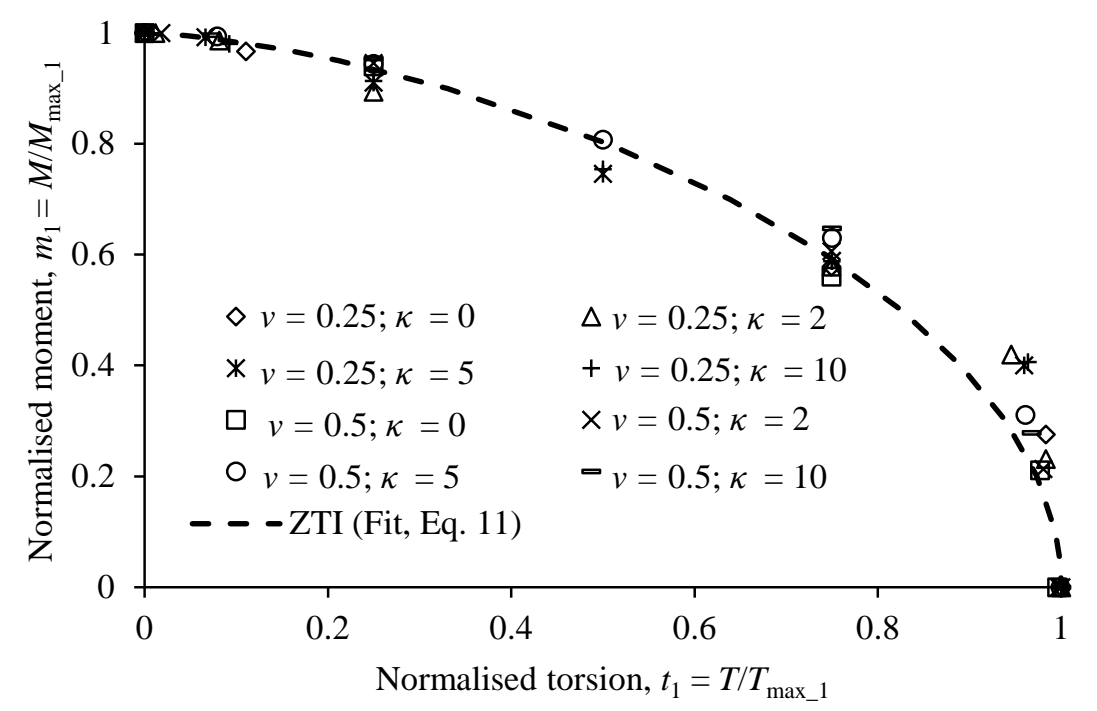

b) $\mathrm{T}-\mathrm{M}_{\mathrm{x}}$ loading $\left(\theta=90^{\circ}\right)$

Figure 17: Normalised T-M failure envelopes for mudmats with ZTI

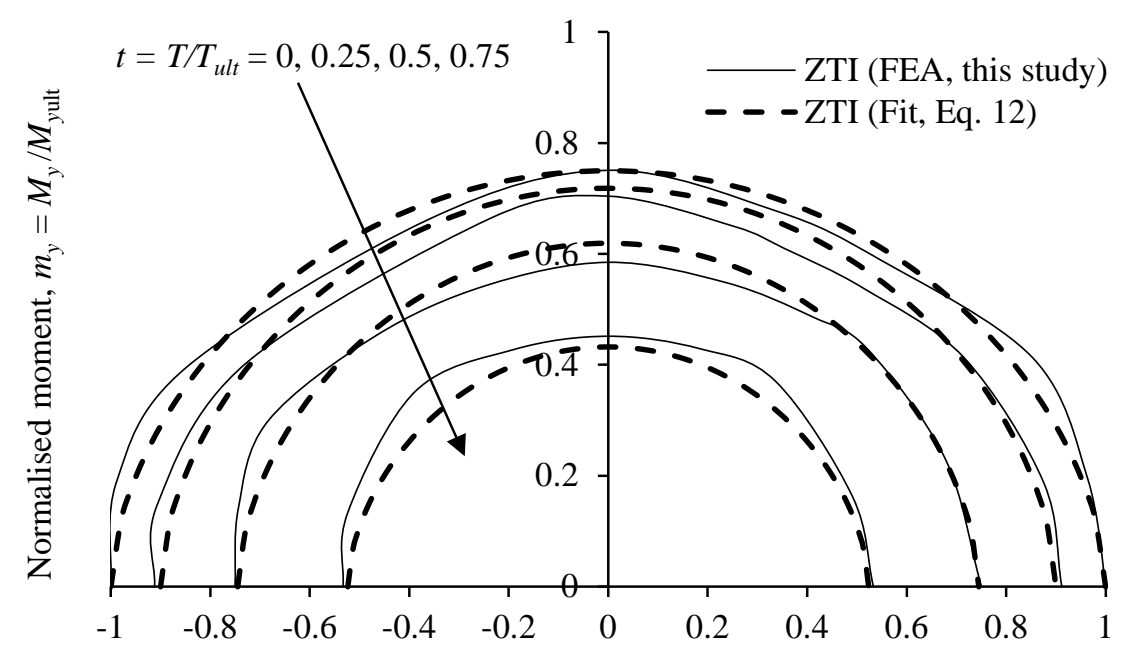

Normalised horizontal load, $h_{x}=H_{x} / H_{x u l t}$

a) $\theta=0^{\circ}, \kappa=0, v=0.25$ 


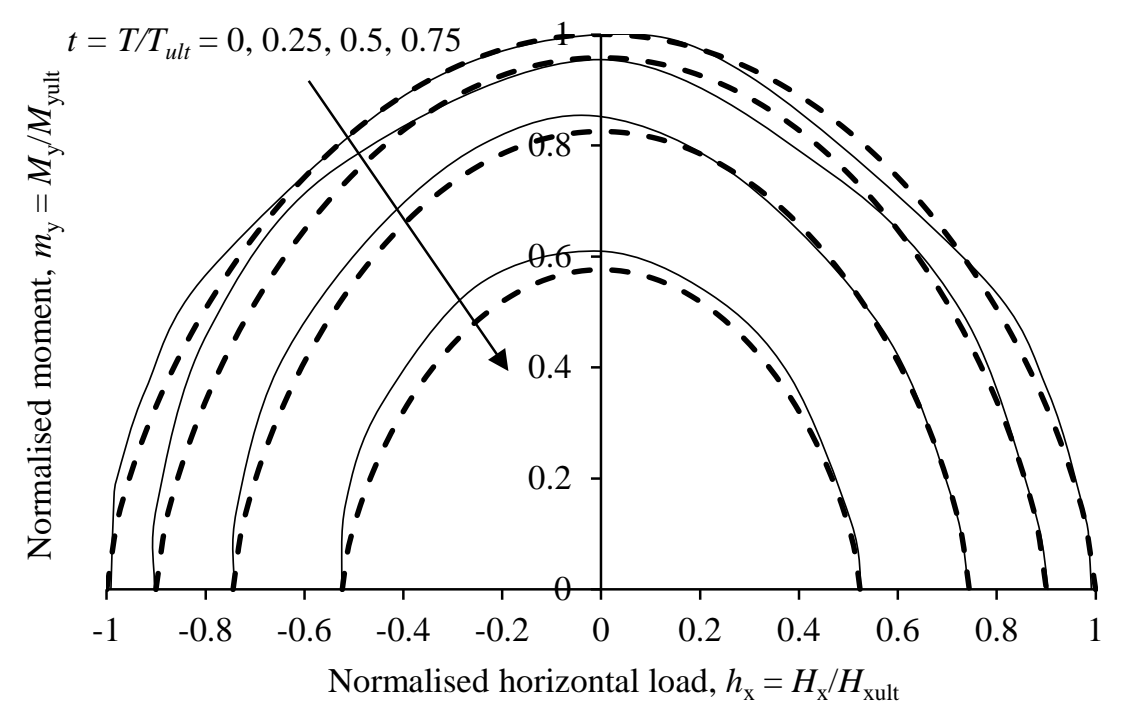

b) $\theta=0^{\circ}, \kappa=0, \mathrm{v}=0.5$

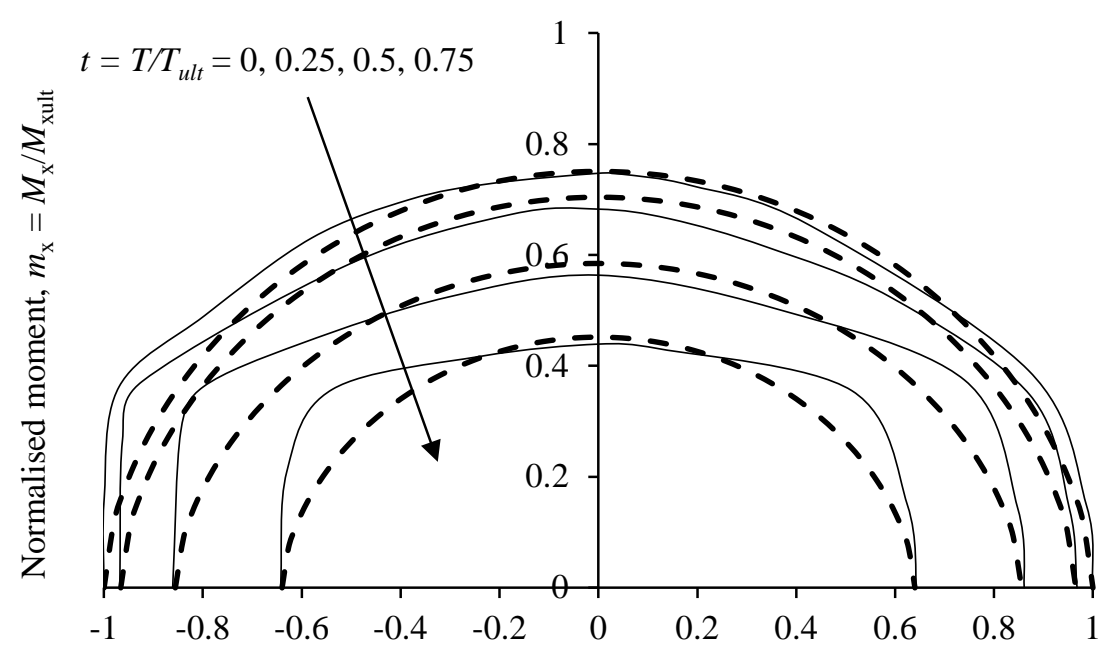

Normalised horizontal load, $h_{y}=H_{y} / H_{\text {yult }}$

c) $\theta=90^{\circ}, \kappa=10, \mathrm{v}=0.25$ 


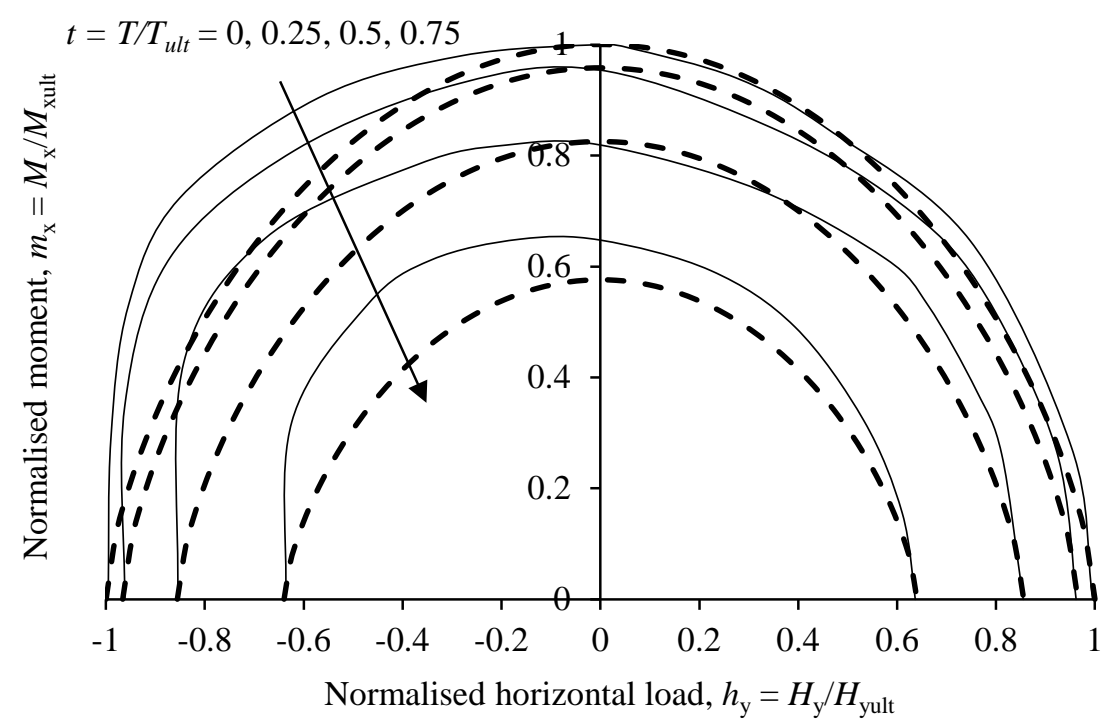

d) $\theta=90^{\circ}, \kappa=10, \mathrm{v}=0.5$

Figure 18: Failure envelopes for mudmats under V-H-M-T loading

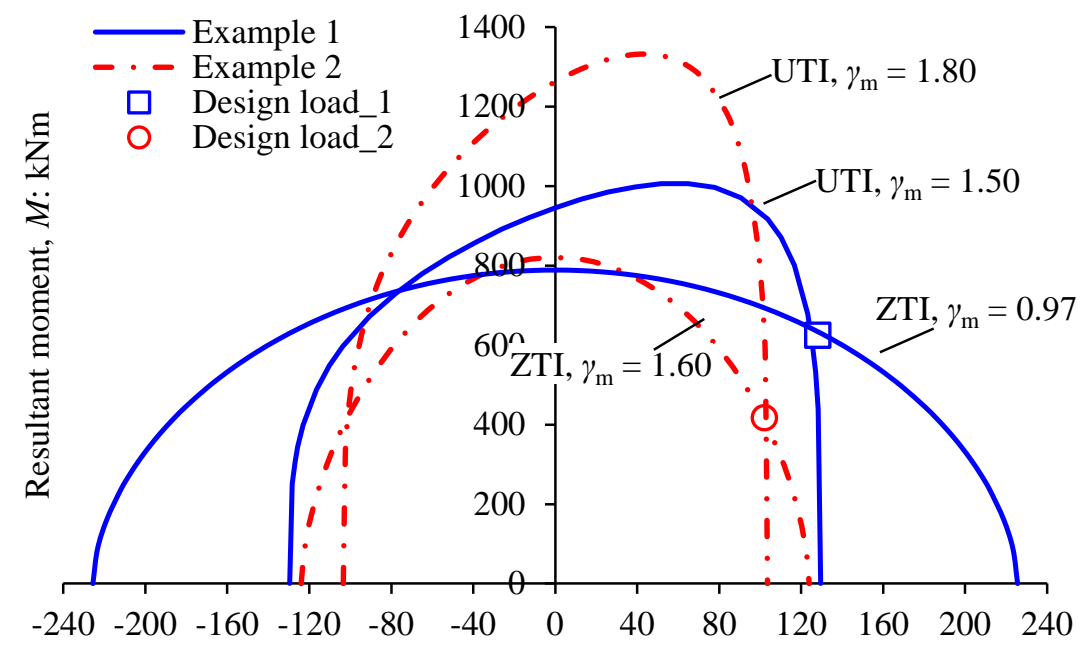

Resultant horizontal load, $H$ : $\mathrm{kN}$

Figure 19: Factored failure envelopes and design loading for example applications 